\title{
The depositional environment and taphonomy of the Homerian "Aulacopleura shales" fossil assemblage near Loděnice, Czech Republic (Prague Basin, Perunican microcontinent)
}

\author{
Nigel C. HugheS, JIŘí KŘíž, JOSEPH H.S. MACQuAKER \& WARREN D. HufF
}

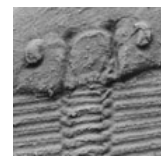

\begin{abstract}
Excavation of Joachim Barrande's classic fossil locality of the "Aulacopleura shales" exposed on Na Černidlech Hill, near Loděnice reveals that most specimens were recovered from a $1.4 \mathrm{~m}$ interval exposed in "Barrande's pits". These are located at the eastern end of a $0.4 \mathrm{~km}$ trench dug in the mid 1800's to expose the interval along strike. Over an hundred bedding planes occur within the $1.4 \mathrm{~m}$ interval, and thousands of articulated trilobites have been collected at the site. Individual bed surfaces vary in the density, size, and taxonomic composition of the fossils contained. Some preserve a diverse benthic shelly fauna, others are almost exclusively dominated by the trilobite Aulacopleura koninckii, and a third variety is apparently barren of all shelly fossils. Isolated sclerites of A. koninckii are rare, and on almost all bedding surfaces exoskeletons are predominantly partially articulated and lack both alignment and sclerite fragmentation. The occurrence of A. koninckii conforms in many ways to the characteristics of a Type I trilobite lagerstätte of Brett et al. (2012). The presence of enrolled A. koninckii suggests that final burial may have resulted from relatively rapid obrution, although the condition of partial articulation indicates that many carcasses or exuviae partially disaggregated before burial. The mean size and density of $A$. koninckii specimens varies markedly among bedding planes, with some assemblages entirely comprised of juveniles, suggesting that notably dense trilobite clustering was not restricted only to reproductively mature individuals. The presence of multiple clusters of different mean specimen size partly accounts from the unusually comprehensive record of the articulated meraspid and holaspid ontogeny of this species at this locality. Limited bioturbation suggests a dysoxic substrate, and the olenimorphic form and distribution of $A$. koninckii, combined with a lack of encrustation or predation upon it, suggests that this species may have periodically bloomed in abundance at particular oxygen concentrations that largely excluded other skeletonized benthos. Some bedding plane assemblages might represent mass mortality events, perhaps as available oxygen passed below levels necessary to maintain the metabolism of A. koninckii. • Key words: trilobite, cluster, Silurian, Barrande, ontogeny, olenimorph.
\end{abstract}

HugheS, N.C., KŘíž, J., MACQUAKER, J.H.S. \& HuFF, W.D. 2014. The depositional environment and taphonomy of the Homerian "Aulacopleura shales" fossil assemblage near Loděnice, Czech Republic (Prague Basin, Perunican microcontinent). Bulletin of Geosciences 89(2), 219-238 (13 figures, 4 tables). Czech Geological Survey, Prague. ISSN 1214-1119. Manuscript received February 4, 2013; accepted in revised form July 22, 2013; published online March 12, 2014; issued May 19, 2014.

Nigel C. Hughes, Department of Earth Sciences, University of California, Riverside, CA 92521, USA; nigel.hughes@ucr.edu • Jiři Kř́̌̌, Czech Geological Survey, Klárov 3, 11821, Praha 1, Czech Republic; silubiv@seznam.cz・Joseph H.S. Macquaker, ExxonMobil Upstream Research Company, Houston, TX 77098, USA; jmacquaker@mac.com • Warren D. Huff, Department of Geology, University of Cincinnati, Cincinnati, OH 45221, USA; warren.huff@uc.edu

A short stratigraphic interval of the Homerian "Aulacopleura shales", exposed on Na Černidlech Hill, near Loděnice, Prague Basin, Czech Republic, has yielded thousands of articulated trilobite exoskeletons that are well represented in collections worldwide. This site is significant in the history of trilobite research as some of the first descriptions of ontogenetic series were based on articulated specimens collected from this locality (Barrande 1852).
Several recent studies of trilobite growth have also been based on material from the site (Fusco et al. 2004, 2014; Hughes \& Chapman 1995, Hughes et al. 1999) with a particular focus on the development of Aulacopleura koninckii (Barrande, 1846). To date, documentation of the palaeoecology and palaeoenvironment of the Na Černidlech Hill site has largely been limited to lists of faunal occurrence (e.g. Vaněk 1990, Kříž 1992). However, a number of ideas inferred to related environmental conditions 


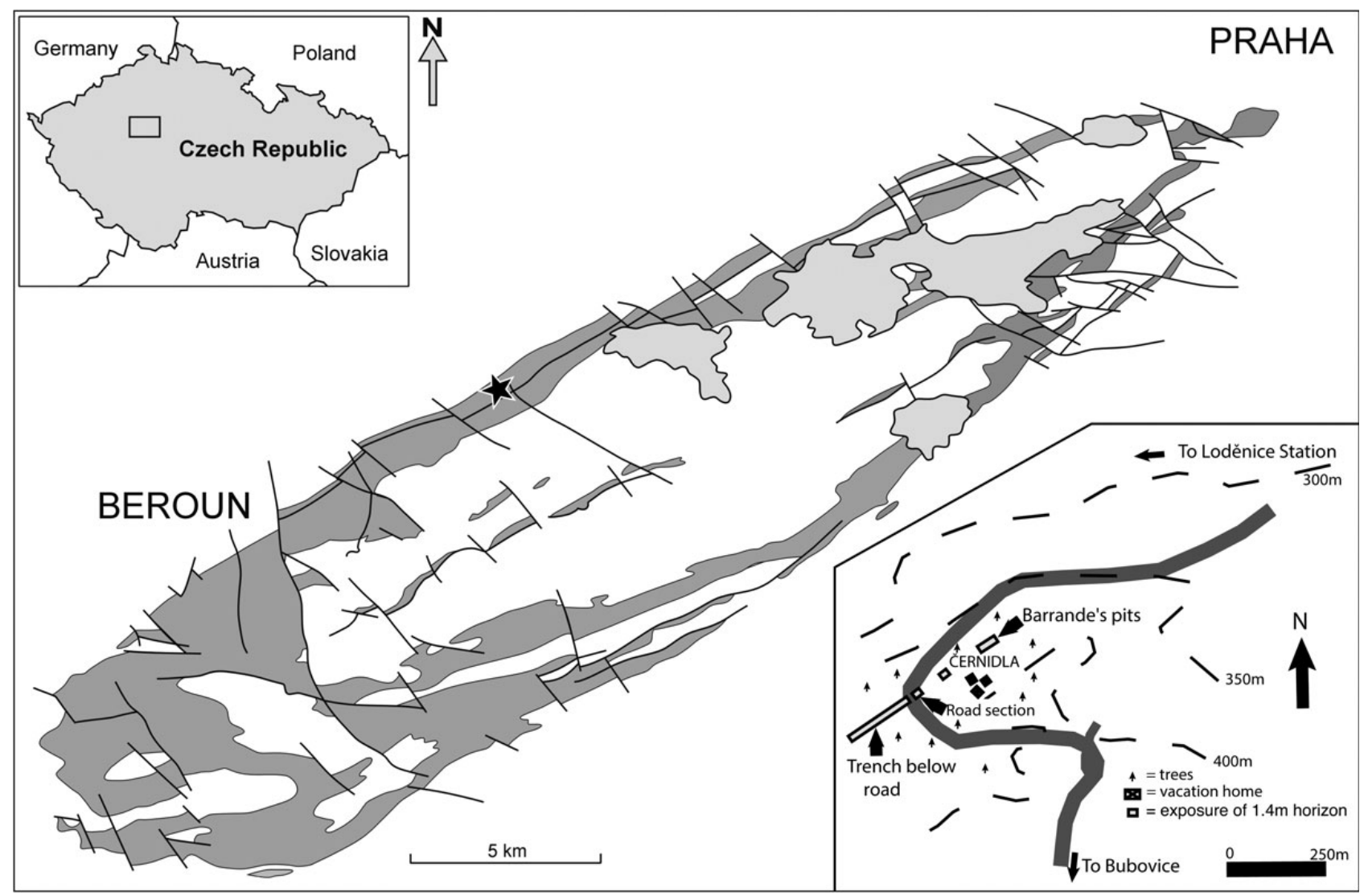

Figure 1. Position of the outcrop area of the Prague Basin within the Czech Republic shown by upper left insert box and approximate distribution of Silurian rocks in the Prague Basin modified from Kř́ž $(1991,1992)$ and Manda (2008) with star showing location of Na Černidlech Hill, near Loděnice. Lower right insert box is sketch map of the location of Barrande's pits in the "Aulacopleura shales", Na Černidlech Hill.

have been proposed to explain both the concentration of and degree of intraspecific variation within trilobites at this level (e.g. Horný 1955; Kř́iž 1962, 1991; Kříž et al. 1993; Vaněk 1990). This paper reports the results of an excavation made at the site in 1995 that was intended to clarify the stratigraphic interval through which Barrande's collections were made, and to assess its palaeoenvironment and palaeoecology both with regard to variation within the unit itself and within the wider context of its regional setting.

\section{Geological setting}

Recent research has shown that global seawater chemistry fluctuated profoundly during the Silurian, and that anoxic conditions may have been periodically widespread (Cramer \& Saltzman 2007, Kř́iž 2007, Kř́žž et al. 2003, Verniers et al. 2008, Melchin et al. 2012). Such fluctuations are well evinced in the Silurian of the Prague Basin that developed as an aulacogen to the Perunican microcontinent (Havlícek et al. 1994, Kř́iž et al. 2003, Křriž 2007). This microcontinent was situated approximately 30 degrees south of the equator, and is thought to have been located some $1000 \mathrm{~km}$ north of the margin of core Gondwanland (Cocks \& Torsvik 2002). The Na Černidlech Hill site is situated on the northern margin of the central segment of the Prague Basin, Barrandian, Bohemian Massif (Kříž 1991, Kř́ž et al. 2003, Verniers et al. 2008). Extensive extrusion of basaltic magmas from at least three volcanic centres located along the northern margin of the central segment resulted in locally shallow and periodically emergent conditions (Kř́ž 1991, 1992). The relatively shallow water facies fringing these volcanic centres received comparatively little continentally derived clastic sediment during the Wenlockian. Contemporary rocks located in both the northern and southern segments of the Prague Basin were graptolite-rich shales, that are interpreted to represent deeper water, persistently anoxic settings (Křǐž 1991).

The Aulacopleura "shales" occupy a $22 \mathrm{~m}$ interval on the western slope of Na Černidlech Hill (see Kříž 1992 and references therein - particularly the detailed sections of Bouček 1941). The unit is mostly comprised of a light to dark brown mudstone with occasional bands of dark limestone up to several $\mathrm{cm}$ thick and its base immediately overlies a prominent $1 \mathrm{~m}$ thick tuffaceous layer. In this region, the top of the Aulacopleura shales is truncated by the 
southern branch of the Tachlovice fault (Horný 1965). The entire unit lies within the Testograptus testis subzone, the upper subzone of the Cyrtograptus lundgreni Zone (high middle Homerian, Upper Wenlock, Silurian), which is widely recognized in the Prague Basin (Křiž et al. 1993), and is estimated to be about 429 million years old (Loydell 2012, Melchin et al. 2012). In addition to the Na Černidlech locality near Loděnice, the distinctive lithology and faunal assemblage of the Aulacopleura shales can be studied near Beroun-Lištice, Praha-Nová Ves at Hemrovy skály, and in the type section of the Aulacopleura shale in "Arethusina Gorge" near Praha-Řeporyje.

The exceptionally detailed stratigraphy of the Prague Basin Silurian (e.g. Kř́iž 1991, 1992; Kříž et al. 1993) indicates that the area was volcanically active over a long interval that encompassed the Wenlock and early Ludlow. The Aulacopleura shales apparently accumulated on the submerged flanks of the Svatý Jan and Reporyje volcanic centres, and during $T$. testis subzone times, the volume of volcanoclastic deposits was relatively low compared to local rocks belonging to zones stratigraphically adjacent both above and below. Volcanic centres are identified via abundant volcanogenic material, and the elevated topography of these volcanic islands resulted in narrow onshore-offshore faunal gradients. Biofacies associations in the region range from a nearer shore coral/crinoid association through a diverse assemblage of brachiopods and trilobites, to a lower diversity Aulacopleura dominated-shale assemblage and finally to dark, graptolitic, calcareous shales (Horný 1955, Kříž 1991, Kříž et al. 1993), and this occurrence pattern is consistent with the inferred preference of Aulacopleura for relatively deeper water settings (Thomas \& Lane 1984). These different associations provide the general context in which this detailed study of the Aulacopleura shales at the $\mathrm{Na}$ Černidlech site is situated.

\section{Barrande's excavations near Loděnice}

Extensive collections on the hillside at $\mathrm{Na}$ Cernidlech were made sometime during the interval between 1830 to 1850 , prior to the publication of Barrande's first trilobite monograph in 1852. A trench was excavated on the northwestern slope of Na Černidlech Hill, and extended southwestward, following the layer along strike for about $0.4 \mathrm{~km}$ (Fig. 1). The trench exposed a short interval of the Aulacopleura shales that was particularly rich in well-preserved fossils, but the thickness of that interval was unknown until our study. The resultant trench can still be recognized, and attests to the scale of Barrande's dig. For reasons discussed below, collecting was primarily focused at the eastern end of this trench in a site informally known as "Barrande's pits" that are located at N $49^{\circ} 58^{\prime} 58.65^{\prime \prime}$, E $14^{\circ} 09^{\prime} 34.04^{\prime \prime}$.
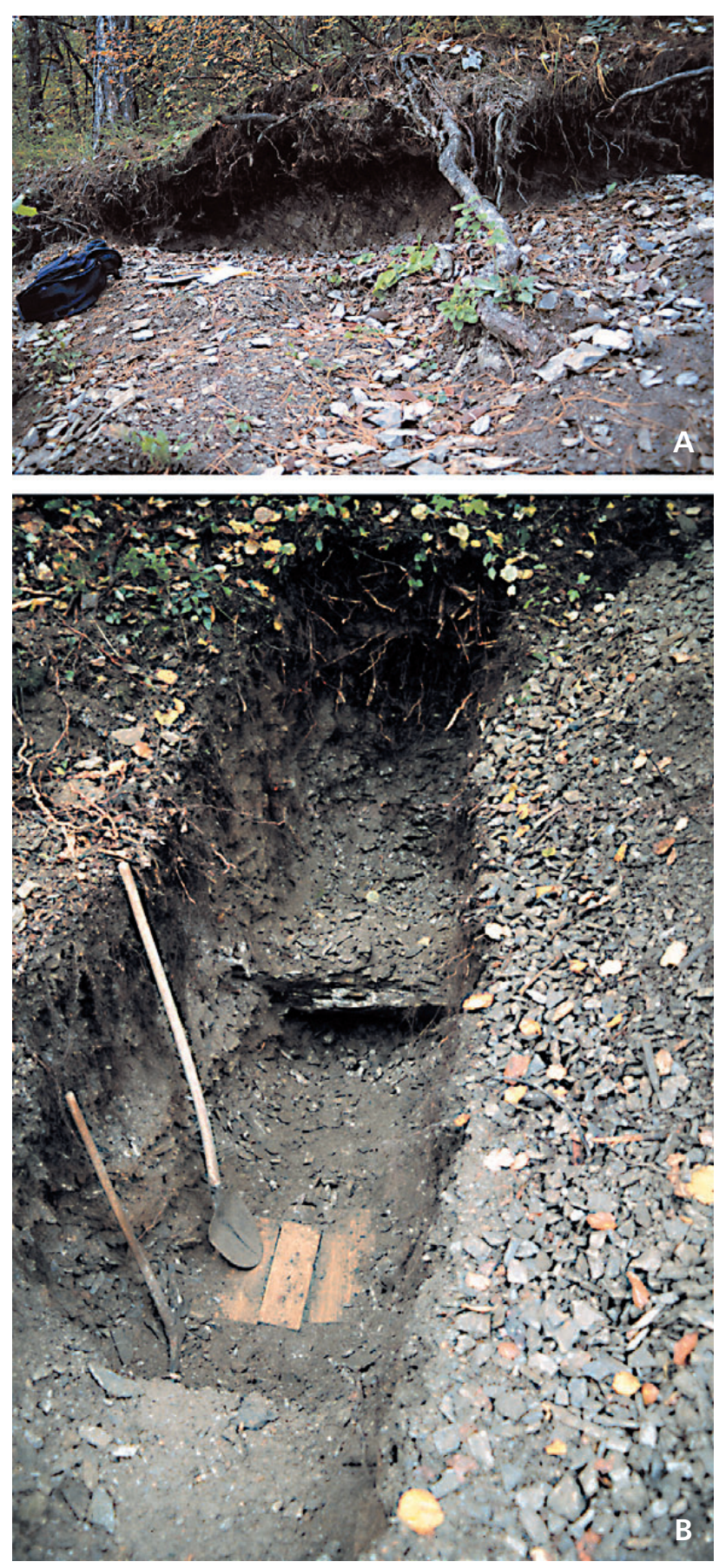

Figure 2. A - the site of Barrande's pit at $\mathrm{Na}$ Černidlech prior to our excavation in October 1995. - B - the excavated trench showing the top of the $1.4 \mathrm{~m}$ interval from which Barrande quarried fossils.

Thanks to permission from the Protected Landscape of the Bohemian Karst Area Agency, in October 1995 two of us (N.C.H. and J.K.) were able to reopen the site of Barrande's most extensive excavation, which cut deeply into the hillside (Fig. 2).

Subsequent to Barrande's time, but prior to our joint work, in the summer of 1958 one of us (J.K.) dug out a 


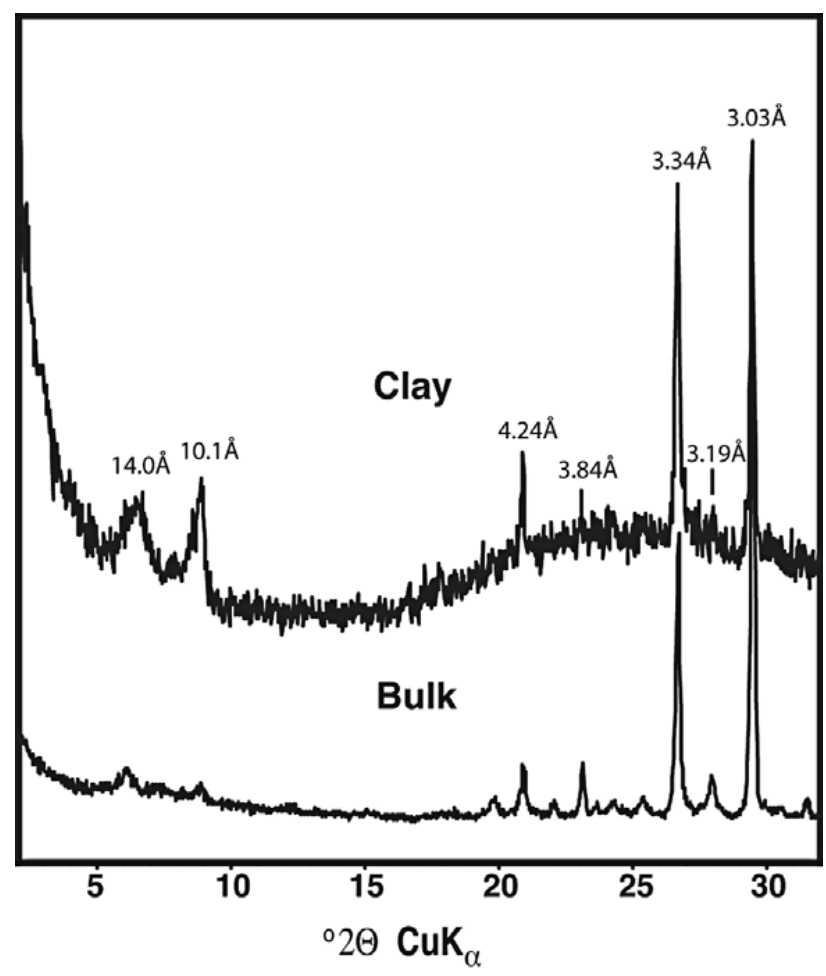

Figure 3. Powder X-ray diffraction patterns a sample from the in situ bed collected at Barrande's pit at Na Černidlech. These include a bulk rock sample and the clay mineral fraction of the dark, finer grained portion of these laminated beds. The whole rock pattern was run on randomly mounted samples while the clay mineral pattern was run on smear-mounted oriented particles $<2 \mu \mathrm{m}$ in diameter. Prominent peaks at $3.34 \AA$ and $4.24 \AA$ indicate the presence of quartz while a strong reflection at $3.03 \AA$ belongs to calcite. Smaller peaks such as those at $3.19 \AA$ and $3.84 \AA$ indicate trace amounts of K-feldspar. The clay mineral trace an asymmetric peak at $10.1 \AA$ is attributable to illite with some amount of mixed layer smectite. Similarly, a broad $14 \AA$ reflection records the presence of a mixed-layer chlorite-smectite phase.

$1.5 \mathrm{~m}$ deep test pit filled with debris from Barrande's excavation that contained abundant complete Aulacopleura (see Kříz 1962). At that time a complete cephalon of Phaetonellus dentatulus (Novák, 1890) with 7 thoracic segments was recovered, and this was important as the species was then only known from pygidia (Křǐz 1962). The Czech Geological Survey undertook an extensive excavation at the site in 1960 (Kř́ž 1962), close to the 1958 test pit. That study identified, but did not excavate, the specific location from which most of Barrande's material was collected. Our excavation dug a trench that was $6 \mathrm{~m}$ long and $3 \mathrm{~m}$ deep through a thick accumulation of debris to expose the place where most of Barrande's material was excavated (Fig. 2B). Barrande's excavation apparently moved progressively along strike, likely toward the southwestward (Fig. 1), digging out the richest interval, splitting the shale on site into hand-sized pieces, and then casting the waste material back into the previously exposed portions of the pit as the excavation proceeded.

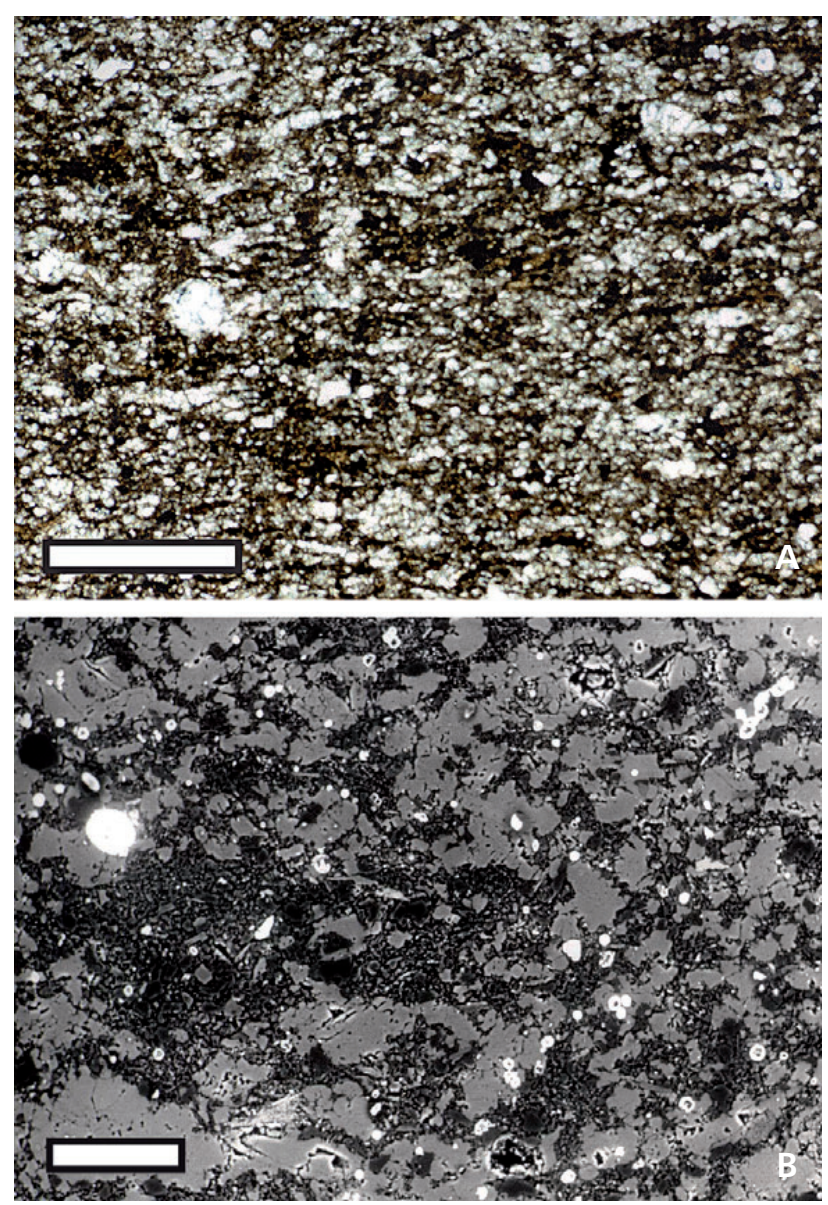

Figure 4. Thin sections of the "Aulacopleura shales" from Barrande's pit at $\mathrm{Na}$ Černidlech. $\bullet \mathrm{A}$ - micrograph in plane polarized light of showing quartz, potassium feldspar, and clay minerals, scale bar is $500 \mu \mathrm{m}$. - B - back scattered electron micrograph showing reflective areas of iron oxide that have replaced pyrite framboids and microcrystalline calcite cement, scale bar is approximately $200 \mu \mathrm{m}$.

Our new excavation revealed that Barrande intensively quarried the $1.4 \mathrm{~m}$ thick interval of dark brown laminated mudstones of the Aulacopleura "shales" that lies directly below a $15 \mathrm{~cm}$ thick indurated carbonate-rich mudstone that contains significant silt. This laminated mudstone, which dipped at 40 degrees $\mathrm{S}$ with a strike of $240^{\circ}$, was so deeply recessed that we were unable to unearth a fresh face (Fig. 2B), but approximately $0.3 \mathrm{~m}$ of brown mudstones were exposed that lay stratigraphically immediately below the recessed interval, and was similar in lithic appearance at both outcrop and thin section scale to the debris containing the abundant articulated trilobites and other fauna. The upper $5 \mathrm{~cm}$ of this $0.3 \mathrm{~m}$ unit was sampled and thin sectioned, and is referred to below as the in situ bed. Thin sections and hand specimens were also taken from several blocks of mudstone from the debris yielding abundant specimens. 
Table 1. Geochemical analyses of carbon and sulphur in samples from the in situ bed, and from specimens in the Museum of Comparative Zoology, Harvard University, bearing different numbers of holaspid thoracic segments. $\mathrm{C}_{\text {tot }}$ is total Carbon, TIC is component of inorganic carbon, TOC is component of organic carbon, $\mathrm{S}$ is sulphur content. No articulated holaspid specimens were available from in situ sample 2.

\begin{tabular}{lccccc}
\hline Sample & $\begin{array}{c}\text { Number of } \\
\text { holaspid } \\
\text { thorasic } \\
\text { segments }\end{array}$ & $\mathrm{C}_{\text {tot }}$ & TIC & TOC & $\mathrm{S}$ \\
\hline In situ sample 1 & 19 & $3.05 \%$ & $2.06 \%$ & $1.00 \%$ & $0.01 \%$ \\
In situ sample 2 & & $4.26 \%$ & $3.15 \%$ & $1.12 \%$ & $0.01 \%$ \\
MCZ 114932 & 19 & $4.36 \%$ & $3.16 \%$ & $1.21 \%$ & $0.01 \%$ \\
MCZ 115940 & 20 & $3.76 \%$ & $2.59 \%$ & $1.17 \%$ & $0.09 \%$ \\
MCZ 116031 & 19 & $5.59 \%$ & $4.60 \%$ & $0.99 \%$ & $0.01 \%$ \\
MCZ 116197 & 22 & $6.02 \%$ & $4.75 \%$ & $0.01 \%$ & $1.27 \%$ \\
MCZ 116198 & 20 & $4.28 \%$ & $2.94 \%$ & $1.35 \%$ & $0.01 \%$ \\
MCZ 114871 & 22 & $4.46 \%$ & $1.14 \%$ & $3.32 \%$ & $0.00 \%$ \\
MCZ 116198 & 20 & $3.89 \%$ & $2.83 \%$ & $0.01 \%$ & $1.06 \%$ \\
\hline
\end{tabular}

\section{Sedimentology}

\section{Description}

Optical mineralogy and X-ray diffraction show the main components of the mudstone to be compositionally immature, and include quartz, potassium feldspar, and clay minerals such as illite and a mixed layer chlorite-smectite phase (Figs 3, 4A). The presence of original pyrite is indicated by molds of iron oxide with relict framboidal textures (Fig. 4B). Lathe-shaped, discoloured and weathered clay grains are visible. Much of the matrix is microcrystalline clay, but in some areas it coarsens to fine silt-sized grains up to $10 \mu \mathrm{m}$ in longest axis length. Some low birefringence grains are acicular, but others have curved surfaces. The matrix contains abundant microporosity, and a small amount of organic matter; it is partially cemented by finely microcrystalline calcite (Fig. 4B). The rock is poorly fluorescent.

Petrographic study reveals a $\mathrm{mm}$ to $\mathrm{cm}$ scale poorly developed lamination with normal grading (i.e. upward fining) in some cases (Fig. 5). The basal laminae in these beds are commonly composed of concentrations of disarticulated shell debris, which grade up into dark brown, organic carbon-rich laminae toward the top. Total organic carbon varied from about 1.0 to $1.4 \%$ among 9 samples analyzed from the in situ bed and $1.4 \mathrm{~m}$ interval. Flattened, finegrained fecal pellets are also present towards the top of these graded units. Hints of a finer-scale lamination are present in some areas. Locally acicular grains are arranged in fan-like manner around a central core, which also contain $\sim 10 \mu \mathrm{m}$ diameter quartz or feldspar grains. These may reflect concentrations of diagenetic gypsum, although geochemical analysis indicate that sulphide/sulphate concentrations are very low ( 0.001 to $1.7 \mathrm{wt} \%$ among nine

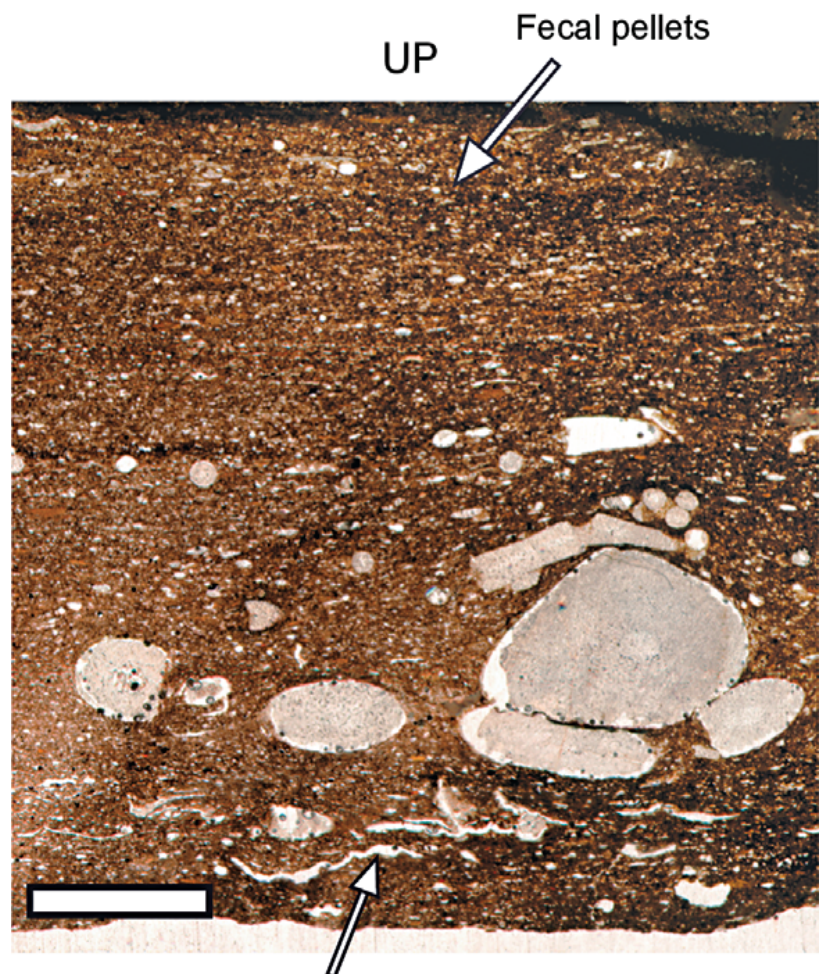

\section{Articulated trilobite sclerites}

Figure 5. Portion of a thin section through the "Aulacopleura shales", from the in situ bed, base of Barrande's 1.4 meter quarried interval at Barrande's pits, Na Černidlech Hill slide CMC IP69859 (Cincinnati Museum Center). Section shows large crinoid columnals preserved in original calcite concentrated, along with recrystallized trilobite exoskeletons, on laminae located towards the base of the bed. Some crinoid ossicles have possible bioerosional structures on their outer parts. Upper layers are darker and more fine-grained, including abundant fecal pellets (see arrows), scale bar is $2 \mathrm{~mm}$ long.

samples analyzed from the in situ bed and $1.4 \mathrm{~m}$ interval, Table 1). These accumulations, particularly the small siliciclastic grains, may more likely represent selective grain agglutination by foraminifera. While individual burrows are not obvious in thin section (Fig. 5), the discontinuous laminae may suggest fine scale churning of the sediment. In hand specimen, narrow, compressed Planolites burrows are widely dispersed (five specimens were recovered in 14 days work at the site).

\section{Interpretation}

The acicular shards suggest that these rocks have a significant tuff component (with the curved surfaces representing the sides of gas bubbles). This is supported by the mixed-layering of the chlorite and illite that is characteristic of the clay component of altered volcanic ash and thus is consistent with a volcanic influence in the origin of these sediments. However, there is no evidence of lapilli, which 
suggests that the tuffaceous component may have been reworked. The crude normal grading suggests subaqueous deposition as part of a waning current, followed by a period dominated by pelagic sedimentation of organic and fecal material. Reworking, if active, was modest because the fecal pellets retain their boundaries. The presence of fecal pellets, possible agglutinated foraminifera, and scarcity of trace fossils argues against extensive bioturbation of the sediment. The original presence of micro-concretionary carbonate and relicts of pyrite framboids indicates that once deposited the pore waters became anoxic and sulphidic below an oxic/dysoxic surface layer, with relatively minimal organic carbon loading. The later decay of pyrite, likely in the Recent weathering zone, altered the local geochemistry and led to dissolution of the presumably low-Mg calcite trilobite exoskeleton. This explains the white powdery texture of the exoskeleton in many trilobite specimens (a condition common in trilobites preserved in dark, organic-rich mudstones; Speyer 1987, p. 227). The low fluorescence is consistent with regional evidence of deep burial of these rocks.

Accordingly, sediment deposition at the site appears to have occurred sporadically sourced by flows that carried a component of tuffaceous material. This was followed by periods of pelagic sediment deposition. A benthic faunal community developed sporadically at the sediment-water interface, but faunal penetration into the sediment was apparently limited throughout the interval. Pyrite framboids indicate sulphidic conditions within the sediment prior to lithification, and elevated hydrogen sulphide levels may have been responsible for limited burrowing.

Given the crude lamination observed in thin section, and the scale of the event laminae that alternate with pelagic laminae, it is likely that the $1.4 \mathrm{~m}$ interval records more than an hundred depositional events (Hughes et al. 1999), separated by surfaces that represent intervals of longer duration. Based on the estimated average accumulation rates of mudstones in slope settings it is estimated that the entire $1.4 \mathrm{~m}$ interval likely accumulated within a period of 1,000 to 10,000 years (Hughes et al. 1999). This interval is shorter than that based on the average $40 \mathrm{~m}$ per million years depositional rate estimated for the entire Motol Formation because accumulation rate is inversely proportional to the interval over which sediment accumulates (Sadler 1981). The nature of the depositional events is unknown, although the fine grain sizes and grading suggest deposition from suspension. A possible mechanism is deposition from buoyant plumes of sediment-loaded water emanating from rivers, i.e. hypopycnal flows (Kohrs et al. 2008). Such flows are capable of transporting fine sediment in suspension for many tens of $\mathrm{km}$ offshore, far from coarsegrained shoreline deposits. These flows require that there is significant density difference between the inflowing plume of water and the receiving water body, and they persist until mixed by surface waves and currents. The flows generally move offshore along a density interface, which in most cases is a well-defined pycnocline.

The lithology of the $1.4 \mathrm{~m}$ interval remains constant westward along the strike of the trench, but the rock becomes more indurated, probably as the result of more pervasive carbonate cementation. Although friability could result from greater weathering at Barrande's pits, specimens from the west preserve original relief better than many from the pits, suggesting that the difference may, in part, predate weathering. The great abundances of specimens at Barrande's pits have suggested to some (Vaněk 1966) that it represents localized concentrations of animals on the $\mathrm{Si}$ lurian seafloor. This abundance of specimens might also result from the friable nature of the mudstone at this site that yields specimens more freely than the better-cemented rocks.

The exploratory geochemical analysis, which shows low sulphur concentration in the mudstones, is consistent with iron oxide staining of many of the fossils, and suggests that the samples have been subjected to intense chemical weathering, which may have remobilized various rare metals. Accordingly, attempts to reconstruct the geochemical conditions associated with the deposition of these rocks do not appear feasible at the site itself although such data might become available from a suitably placed borehole.

\section{Flattening and shear}

The sediment was evidently compacted prior to cementation. This is indicated by the fracturing of shelly material (Hughes 1999; Fig. 6A), and by the ellipticity of some crinoid columnals and all fecal pellets (Fig. 5). The latter are elongated parallel to the plane of bedding. Assuming an originally round cross section, compaction of the in situ bed appears to have led to around $75 \%$ reduction in original relief (Fig. 5). Crinoid ossicles, most of which were apparently articulated, from several thin horizons within one thin section apparently show a more varied response to compaction. Almost all appear to be sectioned in transverse, as opposed to lateral view and, as with the fecal pellets, in all these cases flattened ossicles have their axis of elongation is parallel to bedding, which may support the idea that compaction is responsible for much of the departure from their originally circular shape. This is also supported by the fact that some articulated columnals show evidence of cracking orthogonal to bedding (Fig. 6A). However, it is also possible the elliptical appearance may result from oblique sectioning of a set of stacked pluricolumnals, or that some columnal profiles were elliptical in life (the latter is considered unlikely among Wenlock age crinoids, 
S. Donovan, pers. comm. 2012). Among columnals, which are made of a calcite stereom, apparent elongation was consistently much less than that of fecal pellets, and ranged from between 0 to $50 \%$ reduction in original crosssectional width, with no correlation apparent between degree of elongation and columnal size $(n=15)$.

We conclude that compaction strongly affected these beds, but that its influence depended on the material being compressed. The variable elongation of crinoid ossicles may partially reflect small-scale spatial variation in the degree of compaction. This might explain the rather varied degrees of compaction witnessed among conspecific specimens from these beds (Hughes \& Chapman 1995). Given that the exoskeleton of trilobites such as Aulacopleura koninckii from these beds was much thinner than columnal stereom, but much more robust than the fecal pellets, we would anticipate the degree of compaction in these animals to be on the order of $25 \%$ to $50 \%$. This is consistent with the difference in profile seen between specimens of A. koninckii preserved in this locality and those preserved with original relief from elsewhere (see Hughes \& Chapman 1995, fig. 1c).

A very small proportion $(n=\sim 20)$ of the approximately 10,000 completely articulated dorsal exoskeletons of A. koninckii inspected from this locality have been obviously deformed by shear stress (Fig. 7). Moreover, subtle shearing was also detected within an extremely selective database containing $<4 \%$ of all specimens examined, and from which all specimens showing obvious shear were excluded (Hong et al. in press). In that dataset, shear accounted for less than $5 \%$ of the total shape variance. Like compaction, shear seems to have affected fossils variably within the $1.4 \mathrm{~m}$ interval, and is apparently locally inhomogeneous in its affects. The origin of the shear is unclear: possibilities include localized slippage following partial decalcification during diagenesis, or a very mild tectonic fabric that was apparently localized to specific bedding planes.

\section{The biota of the Loděnice assemblage}

The taxonomic variety recognized in the $1.4 \mathrm{~m}$ interval from Barrande's pits is highly diverse, with the following major groups represented: chitinozoans, conodonts, siliceous sponges, bryozoans, brachiopods (linguliformid and rhynchonelliformid), scolecodonts, foraminifera, gastropods, bivalves, cephalopods, trilobites, ostracodes, crinoids, ophiuroids, dendroid and graptoloid graptolites (Bouček 1941, Kř́̌ž 1992, Vaněk 1966), and in total over 55 species have been recorded from the assemblage, including 21 species of trilobite (Kř́ž 1992, Hughes et al. 1999). This fauna includes both sessile and vagile benthos, in addition to a substantial pelagic component. Crinoids and ophiuro-
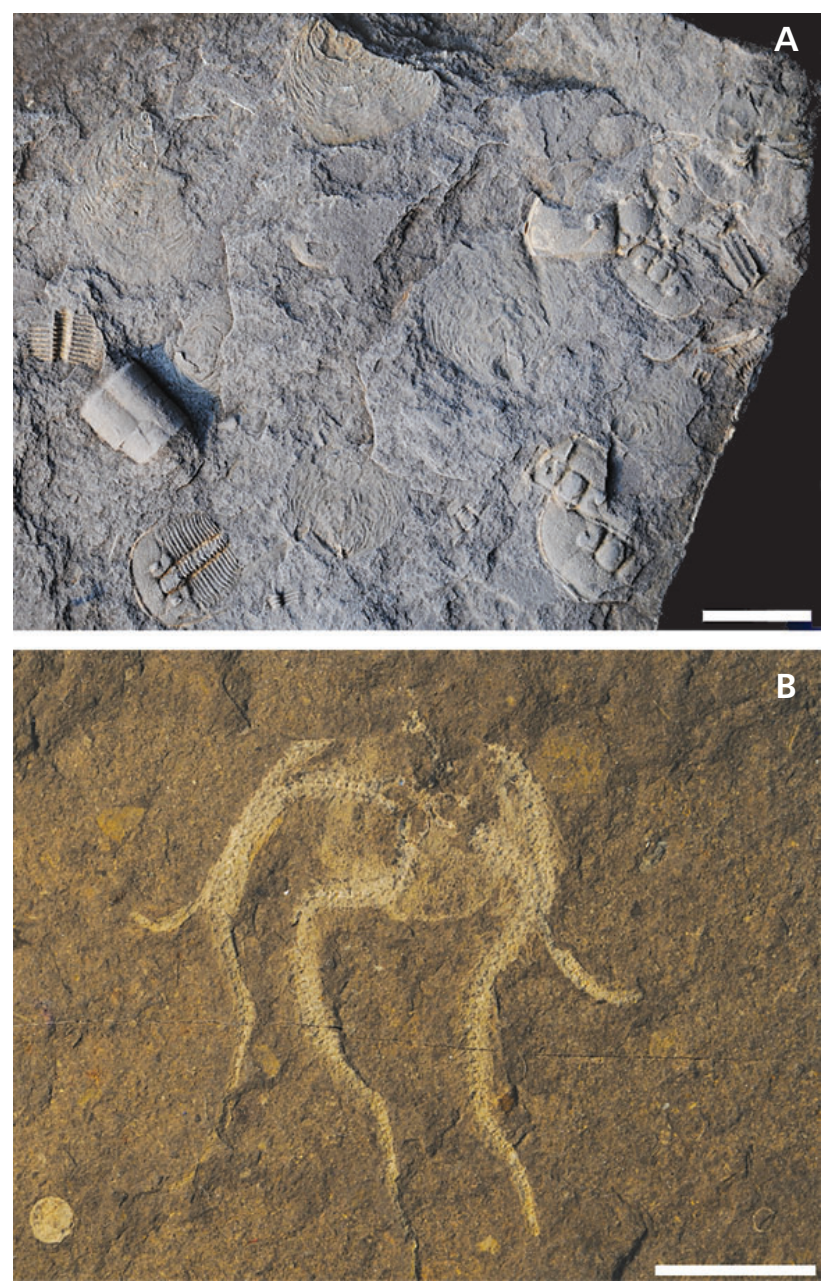

Figure 6. Bed surfaces showing non-trilobite fauna along with A. koninckii from Barrande's pits at Na Černidlech. • A - surface showing cracked crinoid pluricolumnals, five linguliform brachiopod valves lying parallel to bedding, and several specimens of A. koninckii, NPML40689 (National Museum, Prague), slab coated with ammonium chloride sublimate, scale bar in $0.5 \mathrm{~mm}$ divisions. $\bullet \mathrm{B}$ - ophiuroid specimen showing current alignment of arms, CGSp2147 (Czech Geological Survey), scale bar is $10 \mathrm{~mm}$ long.

ids may occur as completely articulated specimens (Fig. 6B) or, more commonly, as partially disarticulated skeletal elements (Fig. 6A). The disposition of the arms in the figured ophiuroid specimen suggests weak alignment, likely by a current. Linguliformid brachiopod valves lie parallel to bedding surfaces, not within burrows in the sediment (Fig. 6A). Variation in the density and diversity of skeletal fossils between laminae is obvious in thin section (Fig. 5) with some layers being dominated by shelly material, occasionally comminuted. Exploitation of the substrate below the sediment-water interface appears to have been limited to minor churning.

With respect to the trilobite fauna, while A. koninckii is overwhelmingly dominant in the $\mathrm{Na}$ Cernidlech assemblage, a large number of other trilobite species are 


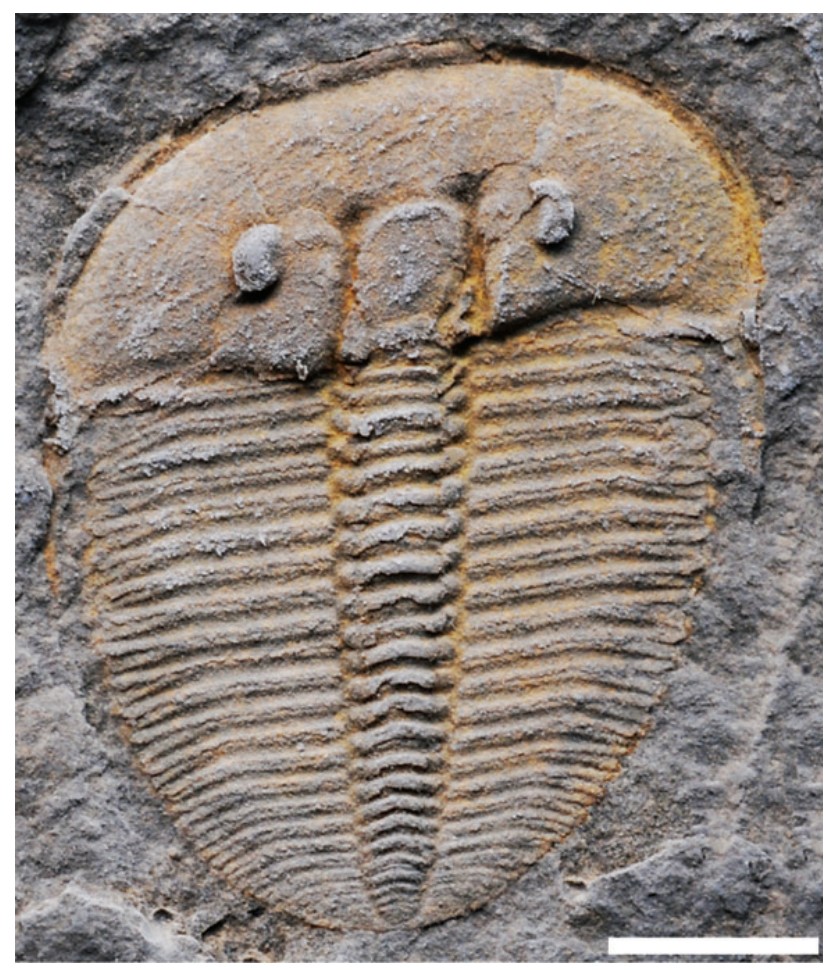

Figure 7. Specimen of A. koninckii from Barrande's pits at Na Černidlech showing simple shear, NPML40711, specimen lightly coated with ammonium chloride sublimate, scale bar is $2 \mathrm{~mm}$ long.

co-occurrent (see Hughes et al. 1999 for illustrations of selected species). All of these are found within the debris from Barrande's pits, but some of the best examples of articulated specimens of Planiscutellum planum and Cheirurus insignis found in museum collections occur in more indurated shales, and we suspect that these were collected further along strike, and perhaps south of the road. However, sclerites of these taxa are found in material from Barrande's pits, and the lithology of articulated specimens of Bohemoharpes naumanii, Odontopleura ovata, Decoroproetus decorus, Scharyia wenlockiana, Cheirurus insignis, Cyphaspis putzkeri, Phaetonellus dentatulus, and Dicranopeltis scabra suggest that all these species were collected from Barrande's pits.

Hughes \& Chapman (1995) could not assess taxonomic variety in their study of museum collections because each slab was sorted by principal taxon and dispersed throughout the Harvard collections. In the new field-based study we compared, at a broad taxonomic level, the biotic variety of the "pooled" collection made from the debris of Barrande's excavation (representing multiple bedding plane surfaces) with that made in situ in the beds immediately below Barrande's excavation (Table 2). Overall the distributions are similar with skeletal elements of $A$. koninckii numerically dominant in both beds. In both collections the most abundant taxa have multi element skeletons, each record of which is counted separately, and the far larger
Table 2. Skeletal element abundance from the in situ and pooled samples collected at Barrande's pits near Loděnice.

\begin{tabular}{lrrrc}
\hline Taxon & $\begin{array}{c}\text { In situ } \\
\text { sample }\end{array}$ & $\begin{array}{c}\text { In situ } \% \\
\text { abundance }\end{array}$ & $\begin{array}{c}\text { Pooled } \\
\text { sample }\end{array}$ & $\begin{array}{c}\text { Pooled \% } \\
\text { abundance }\end{array}$ \\
\hline A. koninckii & 109 & 47 & 242 & 81 \\
Linguliform brachiopods & 10 & 4 & 5 & 2 \\
Rhynchonelliform brachiopods & 4 & 2 & 8 & 3 \\
Crinoid articles & 78 & 34 & 15 & 5 \\
Fenestellid bryozoans & 7 & 3 & 2 & 1 \\
Graptolites & 13 & 6 & 9 & 3 \\
Other trilobites & 5 & 2 & 9 & 3 \\
Molluscs & 4 & 2 & 7 & 2 \\
\hline TOTAL & 230 & & 297 & \\
\hline
\end{tabular}

amount of crinoid material in the in situ bed than in the pooled sample likely over represents the extent to which the fauna of the two intervals differs. Both show a similar array of rarer taxa, with brachiopods, graptolites, cephalopods, bryozoans, and various other trilobites prominent amongst these elements of the fauna. The characteristics of both beds differ somewhat from those reported by Vaněk (1966) who reported quarrying $1 \mathrm{~m}^{3}$ of shales from Barrande's pits, and finding representatives of 17 species within his sample, although $92 \%$ of the specimens identified belonged to A. koninckii. Nevertheless, the overwhelming dominance of $A$. koninckii in the $1.4 \mathrm{~m}$ interval reported by Vaněk (1966) is consistent with our observations. We also agree with him that although many trilobite species are represented in the fauna from Barrande's pits, few are common, and a large number are very rare indeed.

The comparison between the pooled sample and that in situ may suggest that Barrande targeted collecting trilobites at the site, restricting his activities to those beds in which they were most abundant and, like Vaněk (1966), we also find the interval dominated by A. koninckii. Differences in faunal composition among bedding plane collections are not solely the result of differences in the overall abundance of fossils among bedding planes (although such differences do exist), because many beds within the $1.4 \mathrm{~m}$ interval are extremely rich in fossils but are almost exclusively comprised of $A$. koninckii (see below).

The faunal diversity indicates that at times local conditions at the seafloor approached those common in high diversity Silurian benthic communities and the wide range of taxa including sedentary forms such as bryozoans, brachiopods and crinoids, is indicative of times when conditions above the sediment water interface were aerobic and remained so long enough for a diverse assemblage to be established in situ (Savrda \& Bottjer 1987). In such cases, the absence of bioturbation beneath these horizons must indicate that burrowers were precluded from penetrating into the substrate. However, hospitable conditions above the sediment water interface did not characterize the entire 
timespan over which the $1.4 \mathrm{~m}$ interval along with the in situ bed below, were deposited. Many bedding planes have markedly lower diversity, often restricted to very few taxa including large numbers of $A$. koninckii. Some bedding surfaces appear devoid of any skeletal fossils, and occasional layers, up to several mm thick, appear to lack skeletal material entirely. The specific features of the occurrence of $A$. koninckii are considered in the next section.

\section{Taphonomic aspects of the Loděnice $A$. koninckii assemblage}

\section{Previous studies}

Hughes \& Chapman (1995) pointed out that the preservation of a small number of enrolled specimens $(<5 \%)$ from Barrande's pits suggested that final burial of assemblages was by obrution, and that these specimens at least must have been carcasses. Obrution is consistent with the sedimentological evidence presented above. However, these authors also pointed out that, based on a sample of 202 specimens observed on multiple slabs in the Museum of Comparative Zoology lot number MCZ5606 (possibly representing a single or small number of bedding planes within the $1.4 \mathrm{~m}$ interval) that were presumably originally selected for their well preserved specimens, the number of partially articulated exoskeleton of $A$. koninckii greatly exceeds those that are completely articulated (only $29 \%$ of the specimens observed). As a result, they suggested that some of the specimens may represent exuviae, and also pointed out that there was little evidence of fragmentation or corrosion of the specimens. Based on the condition of articulation, Hughes et al. (1999) ventured that individual bedding plane assemblages represent the accumulation of material on a timescale of days to months. The fact that the fauna was broadly consistent among bedding planes within the mudstone, and also within thin limestones associated with the interval also suggested an autochthonous or parautochthonous assemblage (Hughes \& Chapman 1995). The results of our new investigation are consistent with these interpretations.

Fusco et al. (2004) noted that various mature thoracic segment number morphotypes of A. koninckii co-occur on single bedding planes. This conclusion was based on inspection of material from individual museum lot numbers, which shared broadly similar taphonomic characteristics such as cranidial size range, mean specimen density, articulation pattern, associated other fauna, and the nature of exoskeleton preservation including pattern of iron staining (an example being lot MCZ5610 which has holaspid A. koninckii with 18, 19, 20 and 21 segments, respectively). We consider this to be a plausible conclusion, but note that the greatest range of segment numbers observed by us on any single slab is a difference of only one thoracic segment. Slab NMPL2149 has specimens with four holaspid specimens with 19 segments and one holaspid with 20 segments.

\section{This study: description}

Here we present new perspectives on the taphonomy of A. koninckii at the $\mathrm{Na}$ Cernidlech site. Firstly, because Hughes \& Chapman (1995) acknowledged that their museum specimen-based taphonomic study was likely biased, we compare their results to new data collected from the pooled sample, and from the in situ bed. These studies illuminate some of the general taphonomic characteristics of the Na Černidlech assemblage. We then present taphonomic evaluations of particular bedding planes from selected slabs in housed in museum collections to illustrate some of the variety in the taphonomy of the richest and best preserved surfaces.

Material in the pooled sample was discovered on fresh surfaces exposed during splitting of the weathered talus: it is therefore not simply the residual of what Barrande's team left behind after selecting the best specimens, although we do not suggest it to be a completely unbiased sample. Although complete articulated exoskeletons are about three times more common in the MCZ5606 lot ( $29 \%$ of all specimens, $\mathrm{n}=202$ ) than in either the pooled collection (12\% of all A. koninckii specimens, total sample $\mathrm{n}=320$ ) or from the in situ sample (7\% of all A. koninckii specimens, total sample $\mathrm{n}=106)$, in all three the great majority of specimens are at least partially articulated (>80\%) (Fig. 8, Table 3). A notable difference is the high proportion of cephala in our pooled and in situ collections, which in those cases constitute $44 \%$ and $41 \%$ of the total sample respectively, but only $10 \%$ in the MCZ5606 lot. These patterns support the suggestion of Hughes \& Chapman (1995) that Barrande preferentially selected complete specimens for museums, but confirms the overall pattern of sclerite articulation seen in the museum-based sample: the great majority of specimens of $A$. koninckii from the locality are partially articulated, and the assemblage shows a wide range of sclerite articulation states. The results of the in situ sample closely resemble those from the pooled sample, suggesting that partial articulation is a general characteristic of most or all bedding planes within the $1.4 \mathrm{~m}$ interval. Specimen attitude (i.e. way up) was recorded for the in situ collection (Table 3), and shows that roughly half of the specimens, whether articulated or not, were found inverted. We note that the mean size of $A$. koninckii cephala (as represented by cephalic length among articulated exoskeletons and isolated cephala together) is slightly but significantly greater in the pooled sample than in the in situ collection (mean value for pooled sample $=4.3 \mathrm{~mm}$, mean value for in situ sample $=3.5 \mathrm{~mm}, p=0.0008$ ). The 

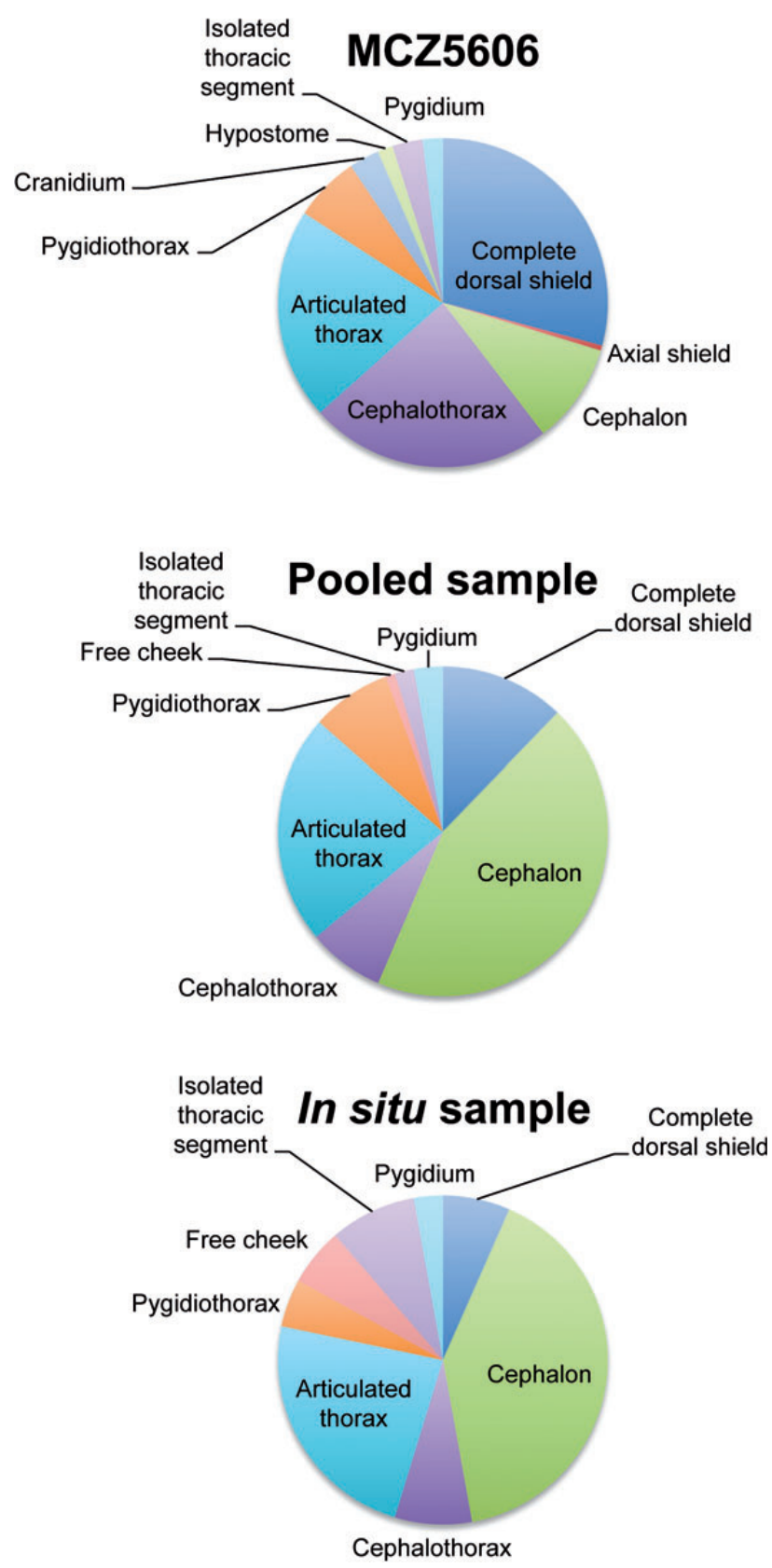

Figure 8. Sclerite articulation in Aulacopleura koninckii from Barrande's pits at $\mathrm{Na}$ Černidlech indicates that all samples are dominated by partial articulation. The museum collection MCZ5606 shows a significantly larger number of complete dorsal shields, while the pooled and in situ collections show a closely similar distribution of articulation states. See Table 3 for data.

distribution of cranidial length in both the pooled and the in situ collection is approximately normal and spans a wide size range (Fig. 9), and almost none of the specimens collected in either sample show evidence of fragmentation, other than compaction-related cracking. The mean length of articulated dorsal shields from both collections is also comparable.

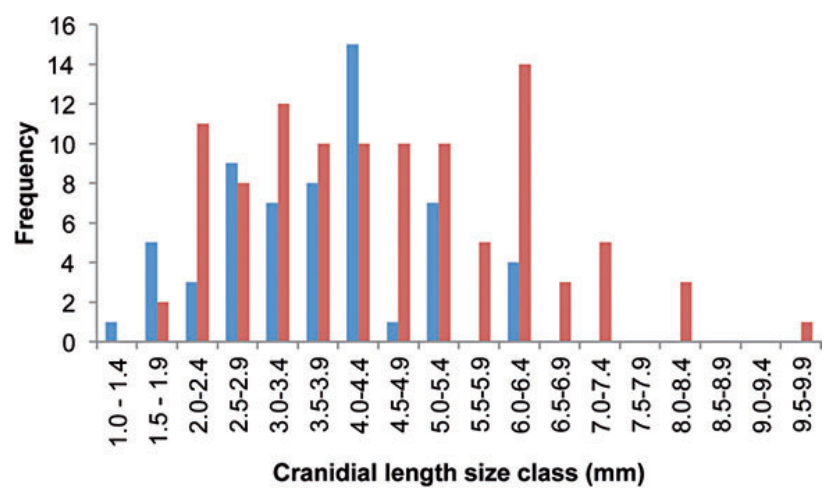

Figure 9. Size distribution, as represented by cranidial length, of $A$. koninckii cephala collected from the pooled sample (red columns) and the in situ sample (blue columns) at Barrande's pits at Na Černidlech. Both approximate normal distributions, and their means differ significantly (see text).

The pattern of articulation described above suggests that bedding planes within the $1.4 \mathrm{~m}$ interval represent a relatively narrow range of taphonomic states compared to the broad spectrum seen amongst trilobites as a whole (see Brett et al. 2012). Nevertheless, analyses of individual slabs show that bedding surfaces do vary notably in certain characteristics. To illustrate this variation, we present data from bedding plane surfaces on four slabs, all of which show dense concentrations of A. koninckii exoskeletons, with few or no other taxa represented.

As in the pooled and in situ samples considered above, all four surfaces (Fig. 10) show the same patterns of partial articulation, and lack fragmentation, inclination and/or tortion (Table 4). Furthermore, no preferred sclerite orientation is apparent on any of these surfaces (Fig. 10). However, the surfaces do show marked differences in mean specimen size, attitude, and density.

A notable difference amongst these bedding planes is in the mean sizes of the A. koninckii specimens. That between NMPL12795 (Fig. 10A), which bears only holaspid specimens, and NMPL39408, NMPL39405, and NMPL12792 (Fig. 10B-D), which are all dominated by meraspid individuals, is obviously significant. Even among the slabs bearing meraspids there is a significant difference $(p<0.0001)$ between the mean size of specimens on NMPL39408 and those on the other two surfaces, but NMPL39405, and NMPL12792 do not differ significantly $(p=0.8529)$. Within NMPL39408, NMPL39405, and NMPL12792 the distributions of glabellar size appear to be approximately normal (Fig. 11), although it was difficult to distinguish very small glabellae from the background matrix when digitizing images, and thus these may be underrepresented in the sample.

As the original orientations of the slabs when collected were not recorded, "convex up" refers to the condition if the bedding surface studied was originally its upper sur- 
Table 3. The condition of sclerite articulation amongst Aulacopleura koninckii from Barrande's pits near Loděnice. "Articulated thorax" implies two or more articulated segments. "Cephalon" does not necessarily imply an in place hypostome. "Cephalothorax" and "Pygidiothorax" imply at least one articulated thoracic segment attached to cephalon or pygidium respectively. Each sample includes data from both meraspid and holaspid specimens, and some cephalothoraces were holaspid.

\begin{tabular}{|c|c|c|c|c|c|c|c|c|}
\hline \multirow[b]{2}{*}{ Sclerite assemblage } & \multicolumn{8}{|c|}{ Collection } \\
\hline & MCZ5606 & $\begin{array}{c}\% \text { of } \\
\text { MCZ5606 }\end{array}$ & Pooled sample & $\begin{array}{c}\% \text { of pooled } \\
\text { sample }\end{array}$ & In situ sample & $\begin{array}{c}\% \text { of in situ } \\
\text { sample }\end{array}$ & $\begin{array}{l}\text { Number of in } \\
\text { situ found } \\
\text { inverted }\end{array}$ & $\begin{array}{l}\% \text { of in situ } \\
\text { inverted }\end{array}$ \\
\hline Complete dorsal shield & 59 & 29 & 39 & 12 & 7 & 7 & 4 & 57 \\
\hline Axial shield & 1 & 0.5 & 0 & 0 & 0 & 0 & & \\
\hline Cephalon & 20 & 10 & 141 & 44 & 43 & 41 & 25 & 58 \\
\hline Cephalothorax & 48 & 24 & 24 & 8 & 8 & 8 & 3 & 38 \\
\hline Articulated thorax & 42 & 21 & 72 & 23 & 25 & 24 & 15 & 60 \\
\hline Pygidiothorax & 13 & 6 & 25 & 8 & 5 & 5 & 1 & 20 \\
\hline Cranidium & 6 & 3 & 1 & 0 & 0 & 0 & & \\
\hline Free cheek & 0 & 0 & 3 & 1 & 6 & 6 & 0 & 0 \\
\hline Hypostome & 3 & 1 & 0 & 0 & 0 & 0 & & \\
\hline Isolated thoracic segment & 6 & 3 & 6 & 2 & 9 & 8 & 3 & 33 \\
\hline Pygidium & 4 & 2 & 9 & 3 & 3 & 3 & 2 & 67 \\
\hline TOTAL & 202 & & 320 & & 106 & & 53 & \\
\hline
\end{tabular}

Table 4. Taphonomic attributes of relatively dense concentrations of A. koninckii from Barrande's pits on bedding surfaces of slabs held in the National Museum, Prague. Note that "cranidiothoraces" occur in those collections dominated by meraspids.

\begin{tabular}{|c|c|c|c|c|}
\hline Figure & NMPL12795 & NMPL39408 & NMPL39405 & NMPL12792 \\
\hline Mean glabellar length & $2.6 \mathrm{~mm}(\mathrm{n}=7)$ & $0.5 \mathrm{~mm}(\mathrm{n}=33)$ & $0.9 \mathrm{~mm}(\mathrm{n}=23)$ & $0.9 \mathrm{~mm}(\mathrm{n}=26)$ \\
\hline Specimen density & $0.007 / \mathrm{mm}^{2}$ & $0.025 / \mathrm{mm}^{2}$ & $0.009 / \mathrm{mm}^{2}$ & $0.014 / \mathrm{mm}^{2}$ \\
\hline "Convex up" & $50 \%(5 / 10)$ & $81 \%(17 / 21)$ & $100 \%(21 / 21)$ & $73 \%(38 / 52)$ \\
\hline Articulation types & $\begin{array}{l}\text { Dorsal shield: } 2 \text {, } \\
\text { Cephalothorax: } 3 \\
\text { Cephalon: } 2 \\
\text { Trunk: } 3\end{array}$ & $\begin{array}{l}\text { Dorsal/axial shield: } 7 \\
\text { Cephalo/cranidiothorax: } 8 \\
\text { Cephalon/cranidium: } 5 \\
\text { Trunk: } 1\end{array}$ & $\begin{array}{l}\text { Dorsal/axial shield: } 4 \\
\text { Cephalo/cranidiothorax: } 11 \\
\text { Cephalon: } 3 \text { Trunk: } 1\end{array}$ & $\begin{array}{l}\text { Dorsal shield: } 4 \\
\text { Cephalo/cranidiothorax: } 23 \\
\text { Cephalon/cranidium: } 11 \\
\text { Trunk: } 14\end{array}$ \\
\hline
\end{tabular}

face. Hence this is only useful in assessing the relative proportions of specimens in each attitude, but it is clear that surfaces do vary significantly in this aspect (from $<75 \%$ to $100 \%$ "convex up"), with one surface showing a uniform orientation, and others showing a mixed condition (Table 4). The latter condition mimics the result from the in situ sample (Table 3).

The density of specimens was estimated by assessing the number of $A$. koninckii glabellae per unit area of the slab (Table 4). Values confirm that bedding surfaces differ in specimen concentration, but that each contains a dense concentration of $A$. koninckii specimens and constitutes a trilobite "cluster" (sensu Speyer \& Brett 1985). Dorsal exoskeletons from beds with relatively low density clusters are commonly more completely articulated than those in dense clusters. However, some specimens in dense clusters are excellently preserved.

Some insight into the pattern of disarticulation may be evident in NMPL12795. The relatively small, fully articu- lated, decalcified exoskeleton in the figured upper left corner (see white star on Fig. 10A) overlaps a large specimen with a decalcified exoskeleton that shows disarticulation with extension at the level of the $6^{\text {th }}$ thoracic segment. This specimen also appears to lack the back of the trunk, but this could have been attached to the counterpart. This specimen in turn overlaps an isolated cephalic shield, and an even more extensively ruptured trunk. A similar relationship is shown by another articulated exoskeleton located towards the base of this image, which overlaps an articulated trunk that is detached from its cephalon. This sequence may relate to accumulation history (see below).

Another notable taphonomic feature of $A$. koninckii evident both on these slabs and as a general property of the whole assemblage is that isolated cranidia (and isolated free cheeks), or articulated axial shields (sensu Henningsmoen 1975), are generally found in specimens in which the glabellar length is $1.5 \mathrm{~mm}$ or less (Figs 10B-D, 12, 13). Below that size isolated cranidia and axial shields are 

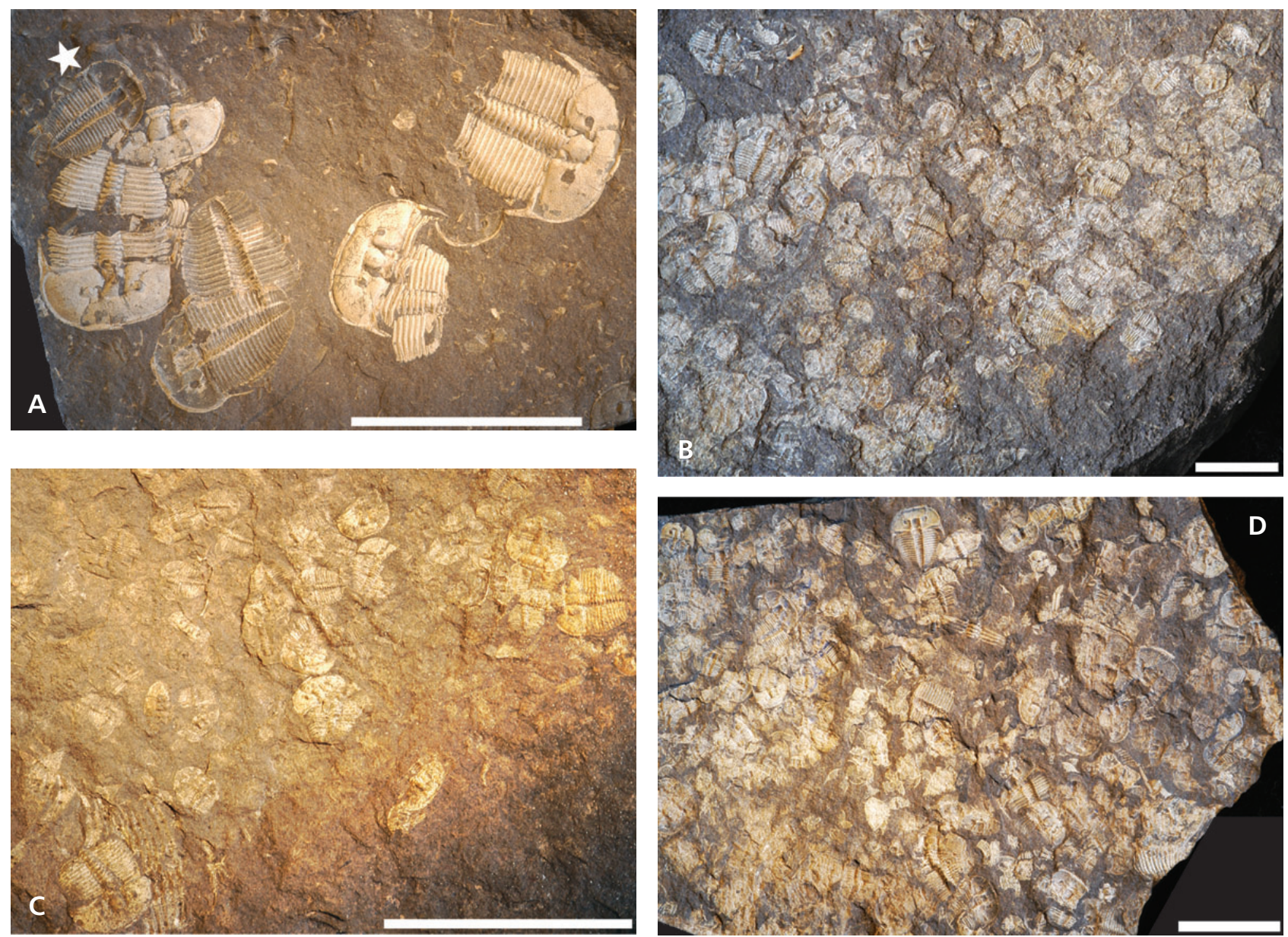

Figure 10. Selected bedding plane surfaces showing the size range, articulation states, specimen density, and attitude of $A$. koninckii specimens from the $1.4 \mathrm{~m}$ interval in Barrande's pits at Na Cernidlech. $\bullet$ A - NMPL12795, showing large, holaspid, partially articulated specimens at relatively low density of occurrence. White star indicates fully articulated, decalcified specimen discussed in text, scale bar is 20 mm long. $\bullet$ B - NMPL39408, showing a dense concentration of small meraspid specimens with many disarticulated cranidia and free cheeks, scale bar is $5 \mathrm{~mm}$ long. $\bullet \mathrm{C}-\mathrm{NMPL} 39405$, relatively low density concentration of later meraspid specimens showing partially articulated specimens with internal ruptures and rotation of sclerites, scale bar is 20 mm long. • D - NMPL12792, high density concentration of meraspid specimens, with disarticulated free cheeks, scale bar is 10 mm long. For associated data see Table 4.

abundant, but above that size, cranidia consistently remain integrated parts of the cephalon, even where the cephalon is detached from the trunk (Fig. 10A).

Among articulated holaspid specimens of A. koninickii the majority show some kind of disruption at the "neck joint" (i.e. between the posterior of the cephalon and the anterior of the trunk), which is largely why less than $4 \%$ of apparently completely articulated specimens could be included in our morphometric analysis of exoskeletal growth (Hong et al. in press; Fig. 14A). Another notable disposition among partially articulated specimens of $A$. koninckii is a single disarticulation within the trunk region that is located in the anterior part of the thorax, at or close to the longest thoracic segment (Fig. 14B).

Beyond these patterns, there is apparently little consistency in the particulars of articulation among A. koninckii. Dorsally articulated cephala, cephala with partial thoraces, articulated portions of the thorax, and portions of thorax articulated with pygidia are all quite common (Fig. 8, Table 3 ).

\section{Interpretation}

If the relatively rare enrolled specimens (e.g. Fig. 13) are taken to indicate animals alive at onset of burial, the range of articulation states suggests that bedding surfaces commonly represent some degree of time averaging. The best preserved specimens may have been alive or moulted shortly before burial, while highly ruptured exoskeletons suggest a period of decay of the carcass or exuvium prior to burial.

The pattern of partial disarticulation combined with a lack of sclerite orientation and fragmentation indicates that the specimens have not been significantly transported. This 
requires a biological explanation for the size selectivity of these A. koninckii associations. A time-averaged accumulation of trilobites, as is seen in the in situ collection, can be expected to show a wide range of specimen sizes. This is because both exuviae and carcasses would contribute to the accumulation, and each large specimen must have experienced multiple prior moults. Although the rarity of smaller specimens likely partially reflects their lower preservation potential, the smallest specimens measured in the in situ collection exceed in size the largest specimens on the lithologically similar slab NMPL39408 (Figs 9, 11), and so delicacy of small specimens alone is unlikely to account for their absence in the in situ collection.

Given that the moult growth increment of A. koninckii is known in the meraspid phase (1.09, Fusco et al. 2004) and the observed size ranges in the three slabs bearing meraspid specimens it is likely that, in each case, individuals making up the assemblage were recruited from several different cohorts (a cohort being a group of individuals that began life together). The range in glabellar lengths in the cluster of $A$ koninckii with the smallest mean size (NMPL39408) is about $0.65 \mathrm{~mm}$ which, given the moult increment observed, likely equates to a span of about 10 meraspid degrees. If the moulting rate of such modern marine arthropods as limulids when at similar size (Sekiguchi 1988) is a guide to trilobite growth, such an array of instars would represent at least one year of cohort growth. As some of the best-preserved specimens are small, it may be unlikely that these assemblages represent the successive instars of either a single or few cohorts, because in that case we would expect positive correlation between degree of articulation and overall size. Such a pattern is not observed.

The lack of both larger and smaller individuals on these surfaces may also indicate that such sized A. koninckii were rare in the community at the time these assemblages accumulated. Although the surface area of each of the slabs is quite small, the absence of larger sized A. koninckii sclerites from any of these argues against their being positively skewed life assemblages in which larger numbers of small individuals simply reflects the combination of high juvenile mortality and exponential growth.

The pattern of variation in specimen attitude among slabs is enigmatic. At the sample sizes available to us we did not observe any obvious association between attitude and other taphonomic characteristics such as degree of articulation, sclerite type, sclerite size etc. that might constrain possible interpretations of this variation.

These surfaces were chosen a priori for their dense concentrations of $A$. koninckii, and the average density of specimens along all bedding planes throughout the $1.4 \mathrm{~m}$ interval would be much lower. Nevertheless, even bedding surfaces with relatively few specimens have inter-specimen distances less than the $44 \mathrm{~mm}$ mean distance reported

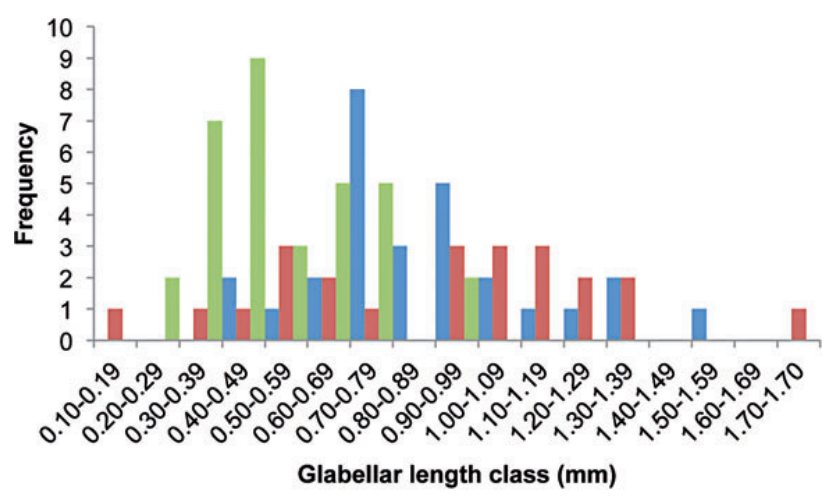

Figure 11. Size distributions of A. koninckii glabellae among measurable cranidia on the studied surfaces of slabs NMPL39408 (green columns), NMPL39405 (red columns) and NMPL12792 (blue columns, from Barrande's pits at $\mathrm{Na}$ Černidlech.

by Hughes \& Cooper (1999) for the Cincinnatian "granulosa" cluster, and it is clear that the Na Černidlech assemblage is one that shows unusually dense concentrations of trilobites. In the most dense clusters the density, when scaled to an area $1 \mathrm{~m}^{2}$, would have substantially exceeded 500 specimens.

With regard to the apparently graded degrees of disarticulation in NMPL12795 (Fig. 10A), if it is assumed that the fossil-bearing surface was originally the upper surface of the slab there is an apparent relationship between the degree of sclerite articulation within individual exoskeletons and the order in which the exoskeletons overlapped one another. If this interpretation is correct, it suggests that the degree of disarticulation is related to the sequence in which the specimens accumulated on the seafloor. The degree of disarticulation may have been proportional to the length of time an exoskeleton (be it carcass or exuvium) was exposed at the sediment-water interface prior to burial. The fact that the fully articulated specimens on this slab are smaller than the more highly ruptured ones would indicate that these are not the successive instars of members of the same cohort.

The abundance of articulated but detached cephala suggests that, as in phacopids (e.g. Crônier et al. 1999), holaspid A. koninckii did not employ the dorsal facial sutures when moulting. [Note that Fusco et al. (2004) estimated transition from the meraspid to holaspid phase at glabellar lengths of about $1.7 \mathrm{~mm}$ in A. koninckii coincident with the transition from an anamorphic to an epimorphic growth pattern (Hughes et al. 2006)]. However, unlike in Weyerites ensae, these sutures continued to be visible throughout the holaspid phase, and often preferentially accommodated movement during compaction, indicating that they remained expressed as vestigial structures where the exoskeleton was relatively weak.

The common disruption of the exoskeleton at the "neck joint" is consistent with the inference that the facial suture did not open during moulting in holaspid 


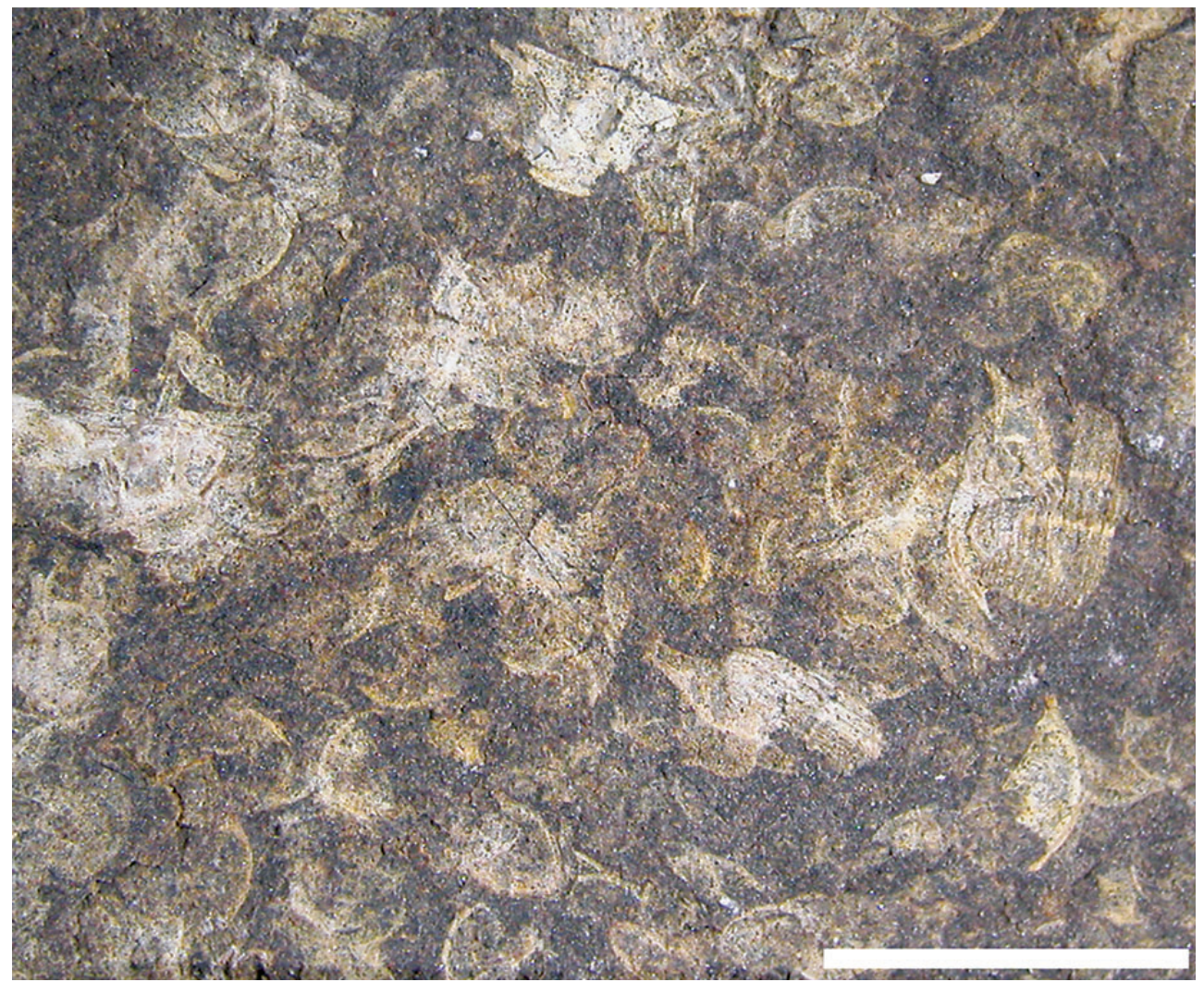

Figure 12. Bedding surface showing abundant disarticulated free cheeks, all of small size, and a small cranidium and partially articulated exoskeleton of A. koninckii specimens from a bedding surface in the $1.4 \mathrm{~m}$ interval in Barrande's pits at $\mathrm{Na}$ Černidlech, scale bar is $5 \mathrm{~mm}$ long. CGS JV13405. No sclerite alignment is evident.

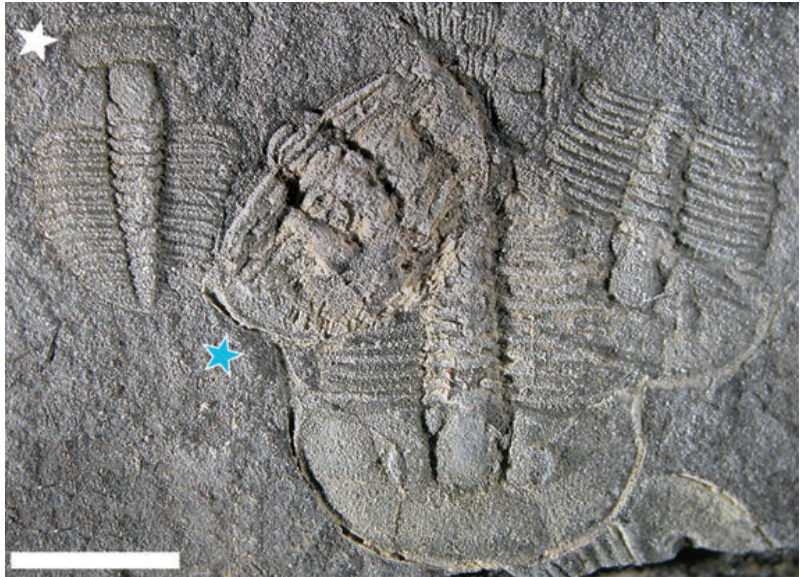

Figure 13. Surface showing several meraspid specimens of $A$. koninckii specimens from the $1.4 \mathrm{~m}$ interval in Barrande's pits at $\mathrm{Na}$ Černidlech lightly coated with ammonium chloride sublimate, scale bar is $20 \mathrm{~mm}$ long. CGS JV13406. Blue star by right cranidial margin of an enrolled specimen, white star by left crandial margin of an axial shield.

A. koninckii. The fact that many articulated specimens of $A$. koninckii show displacement at the neck joint may suggest that a large number of them are, in fact, exuviae. On the other hand, holaspid cephalothoraces presumably indicate partially disarticulated carcasses and are also represented in the collections (Fig. 8, Table 3). Specimens that are ruptured within the anterior part of the trunk might also be moults and curiously, just such a specimen of A. koninckii was illustrated by V.J. Gupta (Gupta \& Shaw 1985, pl. 3, fig. 10) in a bogus paper that claimed to have recovered this species from Zanskar in the Himalaya (see Whittington 1986, Talent et al. 1990). In this case both the form and taphonomy of all the A. koninckii specimens illustrated (Gupta \& Shaw 1985, pl. 3, figs 7, 9, 10, 11) clearly indicates that the material originated at $\mathrm{Na}$ Černidlech.

Although we think that rupture in the holaspid anterior trunk was commonly associated with moulting, we remain cautious about interpreting most individual specimens as either exuviae or carcasses. With the exception of enrolled specimens and holaspid cephalothoraces the wide variation in articulation state witnessed on these bedding planes blurs most boundaries that might have existed between distinctive exuvial postures and those of carcasses. Absent these, it is difficult to distinguish with confidence between ruptured configurations that resulted from vigorous movements during moulting (Brandt 2002) and those that may be related to the decay of carcasses.

\section{Discussion}

The geological setting of the Aulacopleura shales provided a favourable environment for the accumulation and preservation of fossils in the $1.4 \mathrm{~m}$ interval. Episodes of deposition 

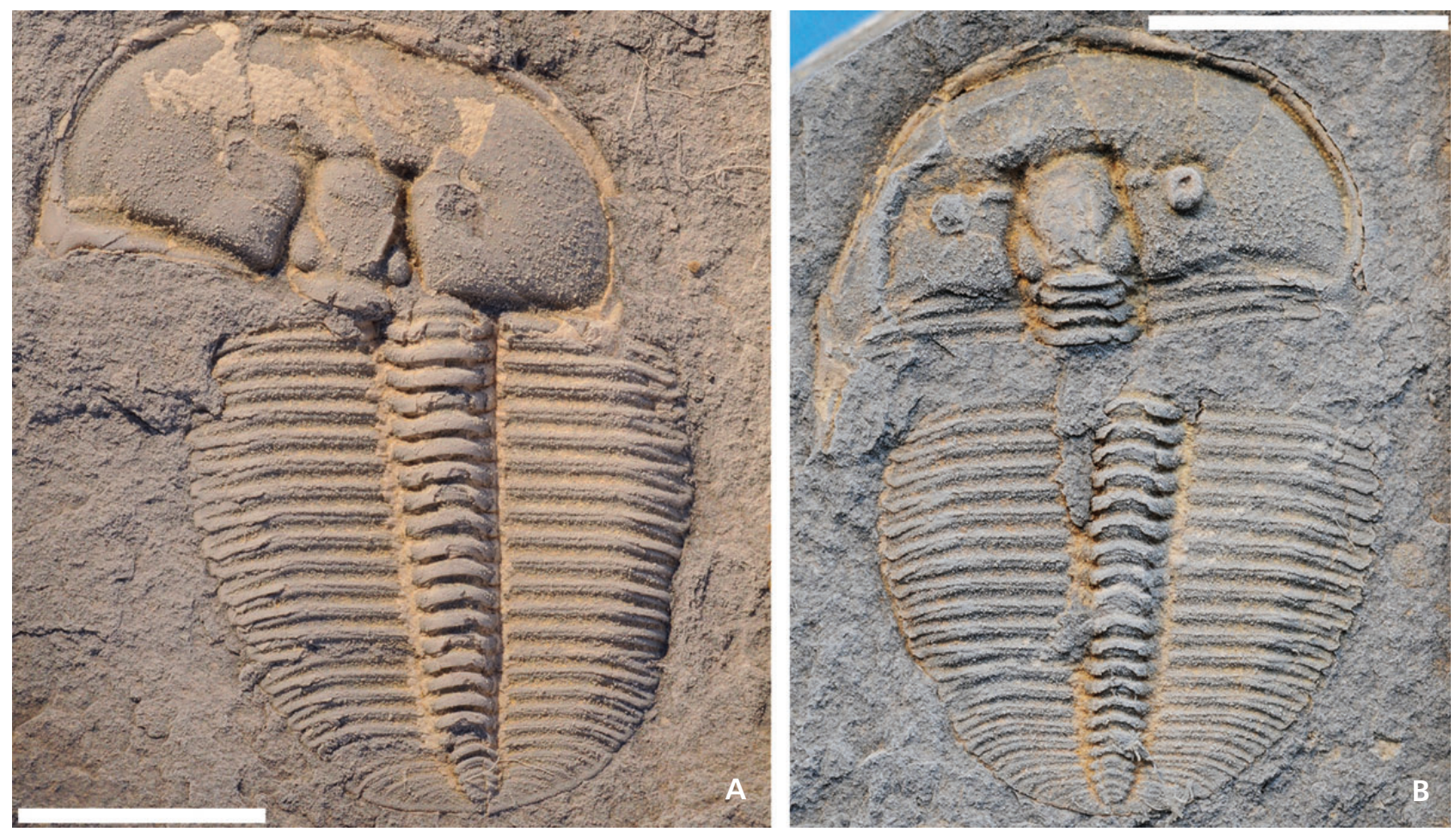

Figure 14. Two holaspid specimens of A. koninckii specimens from the $1.4 \mathrm{~m}$ interval in Barrande's pits at Na Černidlech showing disruption of articulation, both lightly coated with ammonium chloride sublimate, scale bar is $5 \mathrm{~mm}$ long in both illustrations. • A - NMPL40681, holaspid specimen showing rupture at the "neck joint" or cephalic-trunk boundary. • B - NMPL40685, holaspid specimen with rupture occurring within the trunk, between the second and third thoracic segments.

yielded enough material to entomb and preserve articulated specimens (and presumably also kill those specimens preserved in enrolled posture), but to do so without significantly disrupting, fragmenting, aligning, or winnowing shelly material at the sediment-water interface. The $\mathrm{Na}$ Černidlech assemblage thus belongs to the Type I trilobite lagerstätten of Brett et al. (2012) that are characterized by clusters of partially articulated exoskeletons. Such assemblages have been interpreted as the product of burial events induced by hypopycnal flows (see Kohrs et al. 2008). Our sedimentological data are consistent with this interpretation, although whether the inferred depositional setting, on the flank of an offshore volcano, could have fed rivers large enough to generate sufficient hypopycnal flows is questionable. A continental source might be more likely, and this could explain the silica component in the mudstones. Nevertheless, a relatively sediment-starved setting may explain the fact that each individual laminae is thin. Depositional rates between events of mud deposition were slow enough to allow benthic communities to establish themselves repeatedly on the seafloor, but where not slow enough permit the development of thick shell beds, or for extensive comminution of shell debris. Rather, the ranges of articulation states among trilobite exoskeletons suggest that exoskeletons accumulated over intervals spanning weeks to months (Brett \& Baird 1993, Brett et al. 1997, Hunda et al.
2006), and possibly toward the shorter range of this timespan. Hence, given a lack of evidence for any substantive breaks in sedimentation within the $1.4 \mathrm{~m}$ interval the entire thickness may have been deposited within a few thousand years or even less.

Although benthic fauna occurs throughout the interval, particular bedding surfaces differ in both their taxonomic composition and in the mean size and density of A. koninckii specimens. The bed collected in situ shows a range of cephalic size from late meraspids up to quite large holaspids, and this assemblage must include individuals recruited to the population from a wide range of cohorts. On the other hand, the size specific accumulations require a different interpretation, because their limited size range precludes specimen recruitment over a highly prolonged period. These associations represent the exoskeletons of animals that lived together and that accumulated over a period of time no longer than the time it took to grow from the smallest to the largest instars represented in each individual sample. At small sizes this may have been a matter of weeks to months.

Interestingly, all associations examined show some exoskeletons that are ruptured in multiple places, while others are perfectly preserved. A simple explanation for this is that the better preserved specimens are carcasses that were held together more robustly than exuviae, in which sclerite displacement only required rupture of the arthrodal 
membrane. Testing this assertion is hindered by the difficulty of confidently distinguishing carcasses from exuviae.

Articulated juvenile trilobites are generally quite rare in the fossil record. Accordingly, a particular explanation is required for why such large numbers of articulated meraspid specimens of $A$. koninckii occur at $\mathrm{Na}$ Černidlech. Part of the explanation is that because A. koninckii has such a large number of thoracic segments, many of its later meraspid stages are the same size as small holaspids of other co-occurrent trilobites (see Hughes et al. 1999, fig. 1). However, this does not explain why the associations of juvenile trilobites are commonly size specific.

Our preferred explanation for this rests of the following observations:

1. Dense associations of meraspid A. koninckii occur in the absence of other benthic fauna. The only exception is a surface with relatively few trilobites that also hosts several linguliform brachiopods lying with their valves parallel to bedding, along with a short bioclastic crinoid pluricolumnal (Fig. 6A).

2. Conditions within the sediment seem to have precluded extensive reworking by macrobenthos, and sedimentological evidence suggests that pore waters were anoxic.

3. Aulacopleura koninckii belongs to the "olenimorphic" trilobite morphotype that is considered specifically adapted for life in conditions of relatively low oxygen availability (Fortey 2000). This morphotype is characterized by segment rich thoraces with laterally extended pleurae, thin exoskeletons and, while including many representatives of the order Olenida, also includes other trilobites such as Aulacopleura (Fortey \& Owens 1990, p. 140).

Considering these, we posit the following scenario. During various periods of the deposition of the $1.4 \mathrm{~m}$ interval normal oxygenation conditions pertained at the sediment-water interface. During these times a diverse benthic assemblage of macroinvertebrates developed on the seafloor. Aulacopleura koninckii was likely present in such biotas. At other times conditions of restricted oxygen availability extended above the sediment-water interface, with the result that most other benthic fauna was restricted or excluded. The olenimorphic Aulacopleura koninckii (accompanied on some bedding planes by linguliform brachiopods) was able to tolerate such conditions, and sometimes occurred in large numbers, completely dominating the skeletal fauna. We therefore interpret Aulacopleura koninckii to be a poikiloaerobic organism (Allison et al. 1995), able to tolerate a fluctuating oxycline, and thriving in conditions that excluded most other shelly benthos.

Bedding plane assemblages such as the one collected in situ, which contain A. koninckii of a wide range of sizes likely represent the accumulation of shelly material over a relatively protracted period, although the final burial of this layer was likely a relatively rapid event. Dense accumula- tions of A. koninckii at particular size ranges are biological associations that must represent individuals recruited from a smaller number of cohorts. As many of the specimens are partially articulated, these may represent moult ensembles, although excellently preserved specimens demonstrate that some were preserved without significant sclerite displacement. It is also possible that the pattern of partial articulation represents animals that congregated together at the sediment-water interface and then were killed simultaneously, with the partial articulation representing decay prior to burial. In either scenario, the clustered assemblages likely represent animals that were alive together and that represent a relatively small number of cohorts. It is possible that they represent temporary "blooms" in the population size of $A$. koninckii that responded to fluctuations in the levels of available oxygen at the sediment-water interface. According to this interpretation, A. koninckii was an opportunistic benthic species adapted to conditions of low oxygen availability in which other elements of the shelly benthos were commonly excluded. The $1.4 \mathrm{~m}$ interval thus attests to multiple episodes of the establishment and demise of the benthic community, with A. koninckii repeatedly blooming in abundance at particularly favorable oxygen conditions, but perhaps also suffering periodic mass mortality when oxygen levels dropped below the minimum needed to maintain metabolic viability.

The concentration of trilobites at $\mathrm{Na}$ Černidlech (and other similar accumulations in the vicinity) have previously been explained as mortality events caused by short catastrophic events related to volcanism in the area (Horný 1955, Kříž 1991, Kř́iž et al. 1993). Possible mechanisms include smothering of assemblages by volcanic ash, or rapid effusion-related changes in seawater chemistry. The presence of the multiple fossiliferous bedding surfaces within the $1.4 \mathrm{~m}$ interval rules out explaining the entire assemblage as the result of a single catastrophic event, but multiple such events remain probable. However, as the tuffaceous component of the sediments is relatively small, there is no evidence of repeated smothering by ashfall. Furthermore, even major ashfalls do not necessarily result in the catastrophic death of the resident benthic marine fauna (Huff et al. 1992). Volcanically-induced geochemical poisoning remains possible.

Aulacopleura koninckii is also known from several other localities in and around the Beroun region of Bohemia (and the species is also recorded in other parts of Europe, see Hong et al. in press). However, although several of these other localities have lithofacies that are similar to those in Barrande's pits, none of them is known to yield specimens in similar abundance. Hence it is possible that the site of Barrande's pits was persistently attractive to benthic fauna (for example, perhaps located near a nutrient source, such as a seafloor seep) but currently there is no independent evidence for this. 


\section{Comparisons with other trilobite lagerstätten}

Brett et al.'s (2012) classification of trilobite lagerstätten distinguishes concentrations of partially articulated specimens that are generally prone, clustered, and not current aligned (Type I) from those associations of articulated exoskeletons that show evidence of entrainment within a moving flow (Type II). As Na Černidlech is clearly among Type I, our comparisons are primarily restricted to other examples of this type. In Type I assemblages the concentration of exoskeletons on the bedding surface and their subsequent burial are considered to be separate events, although these may be genetically related.

Amongst Type I trilobite lagerstätten there is a difference between associations of exoskeletons that show little or no disarticulation, and those that show partial disarticulation, but with sclerites commonly arrayed in a consistent manner. The former are generally interpreted to represent associations of carcasses or "body clusters" (e.g. Gutiérrez-Marco et al. 2009), while the latter are considered to be "moult ensembles" or "moult clusters" (e.g. Karim \& Westrop 2002, Speyer \& Brett 1985). Body clusters imply that the animals died while clustered, but this need not be the case for moult clusters. However, distinction between body and moult clusters is not always clear. Although frequent disruption of the "neck joint" may suggest that many partially articulated holaspid A. koninckii represent exuviae, the presence of a sizable number of complete, articulated specimens that show no obvious sclerite displacement (including enrolled specimens), and of holaspid cephalothoraces, distinguish the Na Černidlech assemblage from typical "moult ensembles". Thus, variable degrees of time averaging among the different bedding planes obscure distinction between body and moult clusters at $\mathrm{Na}$ Černidlech, although it is clear that A. koninckii were repeatedly congregating there in dense, localized clusters.

The preservation of both body and moult clusters have been linked to environments in which benthic oxygen levels were generally low, and in some cases the preservation of body clusters has been suggested to relate to mass mortality due to insufficient oxygen (Brett et al. 2012, Chatterton \& Ludvigsen 1998, Gutiérrez-Marco et al. 2009). A particularly apt comparison may be that made with a study of the occurrence of the "ptychopariid" trilobite Elrathia kingii from middle Cambrian rocks of the Wheeler Shale of Utah (Gaines \& Droser 2003). Both E. kingii and A. koninckii share the olenimorphic morphotype although neither appears to be closely related to trilobites of the order Olenida, and so this similarity is indeed convergent. Both species also vary in the number of thoracic segments expressed in the holaspid phase, although variance is much less marked in E. kingii (see Bright 1959) than in A. koninckii (see Fusco et al. 2004,
Hughes et al. 1999). Gaines \& Droser (2003) pointed to the occurrence of dense, monospecific accumulations of E. kingii in unbioturbated sedimentary rocks that alternated with beds showing evidence of both higher and lower levels of oxygenation. These characteristics mimic those of the occurrence of A. koninckii at Na Černidlech. Gaines \& Droser (2003) interpreted $E$. kingii to be an evolutionarily early occupant of the exaerobic zone of Savrda and Bottjer (1987), which is located at the interface of dysoxic to anoxic conditions, and inferred that the species may have fed on sulphur reducing bacteria. A further possibility is harvesting such bacteria in a chemosymbiotic relationship, as inferred by Fortey (2000) for the olenid trilobite Triarthrus.

The occurrence of $A$. koninckii at $\mathrm{Na}$ Černidlech resembles that of $E$. kingii in many respects, but there are also some differences. The Wheeler Shale shows notable variations in the extent of bioturbation between adjacent beds, and these variations correlate with the composition of the benthic assemblage. Within the $1.4 \mathrm{~m}$ interval at $\mathrm{Na}$ Cernidlech all beds are either ichnofabric index i or ii (Droser \& Bottjer 1986), yet associated bedding planes have diverse benthic faunas in some cases. Furthermore, although A. koninckii clearly "bloomed" at particular times in a manner similar to that of E. kingii it is also found on bedding planes with a diverse benthic fauna (although it is not clear that the co-occurrence was exactly contemporaneous). For this reason it may better be classed as a poikiloaerobic species rather than an exaerobic one. It may be possible that the greater apparent intraspecific variation in holaspid thoracic segment numbers in A. koninckii enabled it to live in a slightly wider range of environments than $E$. kingii. If so, we might predict that segment-poor holaspids are more likely to co-occur with other benthic fauna, and segment-rich forms more likely to occur in monospecific assemblages. This prediction is based on the idea that the number of trunk segments relates directly to available surface area for respiration or culturing sulphur-reducing bacteria (see Suzuki \& Bergström 2008 for a different but related view on the association between segmentation and surface area for respiration), and that monospecific assemblages reflect more extreme conditions that excluded most other benthos.

With regard to A. koninckii, although it might be possible to infer its occupancy of a zone of reduced oxygen availability based on the fact that its occurrence fulfills the physical criteria for recognizing this zone, we have not found any evidence of association with sulphur-reducing bacteria. Likewise, a recent analysis of the occurrence of Triarthrus eatoni (see Farrell et al. 2011) failed to detect evidence of a chemoautotrophic life mode for that animal. The occurrence of Triarthrus at Beecher's trilobite bed also invites comparison with that of A. koninckii, but differs in that the trilobites are current aligned and often inclined to bedding, and thus transported. That assemblage belongs to the Type II lagerstätte of Brett et al. (2012). 
Paterson et al. (2007) described the taphonomy of trilobites on a variety of bedding planes of early Cambrian age in the Emu Bay Shale of the Adelaide area of South Australia. These authors contrasted a surface with multiple, complete exoskeletons of Balcoracania dailyi that showed a positively skewed size distribution, which they interpreted to be a life assemblage, with other surfaces with normal sclerite size distributions and in which the degree of disarticulation were notably higher. These they interpreted to be time averaged accumulations. In terms of taphonomic condition most $\mathrm{Na}$ Černidlech bedding plane assemblages apparently lie in an intermediate position, as their degree of articulation is considerably higher than that of Paterson et al.'s (2007) time averaged accumulations, but lower than that of the suggested life assemblage.

Webster et al. (2008) described a $0.43 \mathrm{~m}$ unit of early Cambrian rock from Ruin Wash, Nevada, in which the preservation of trilobites varied along a continuous spectrum ranging from fully articulated specimens that may have been carcasses of animals alive at the time of burial, to time averaged shell pavements comprised almost exclusively of cephala. The articulation state of the $\mathrm{Na}$ Cernidlech material lies towards the well-preserved end of this spectrum. Despite the variation between bedding surfaces detailed below, compared to both the Emu Bay Shale and Ruin Wash examples, the Na Černidlech site shows notable overall consistency in its taphonomic signature, suggesting that broadly stable depositional conditions persisted during the deposition of the $1.4 \mathrm{~m}$ interval. The possibility of cyclic variation in the preservation of the biota and in oxygen levels could be profitably assessed by drill core located away from the weathered zone.

Two assemblages that may bear further comparison with that of $\mathrm{Na}$ Černidlech include the slightly younger Otarion diffractum assemblage at Kosov Quarry (see Hughes et al. 1999), and the Devonian Paraaulacopleura inexpecta assemblage (Chlupáč 1983). Both contain significant numbers of articulated trilobite exoskeletons including the eponymous homeomorphs of A. koninckii, and these may suggest that some particulars of the palaeoenvironmental setting of the $\mathrm{Na}$ Cernidlech assemblage were iterated several times in the region.

The singular characteristic of the $\mathrm{Na}$ Černidlech assemblage is the preservation of large numbers articulated meraspid trilobites in association with articulated holaspids of the same species (see Hughes et al. 1999). Large numbers of articulated meraspids are rarely recorded, although their repeated discovery by Barrande (1852) in rocks from at least three different systems in Bohemia may imply that they have been overlooked elsewhere. Our study reveals that at $\mathrm{Na}$ Černidlech certain intervals of meraspid growth characterize particular bedding planes, rather than all stages being found together in approximately equal abundance on individual bedding planes (e.g. Lin \& Yuan
2009), although articulated meraspids and holaspids do co-occur together on some surfaces at $\mathrm{Na}$ Cernidlech. Speyer \& Brett (1985) suggested that dense trilobite clusters might reflect congregations of animals related to breeding, with the animals possibly moulting prior to mating. In some cases specimens in different clusters have different mean sizes and, as additional dense clusters have been described (e.g. Gutiérrez-Marco et al. 2009, Karim \& Westrop 2002, Paterson et al. 2007), the idea that such clusters reflect reproductive activity has gained currency, although other reasons for clustering such as feeding (Fortey \& Owens 1999), or protection (Hughes \& Cooper 1999) have been suggested. Although the timing of onset of sexual maturity remains obscure in the ontogeny of any trilobite (Hughes et al. 2006), the presence of non-transported meraspid clusters of $A$. koninckii suggests that clustering behaviour was almost certainly unrelated to collective reproductive activity in this case.

\section{Summary}

Re-excavation of the site of Barrande's quarry at Na Černidlech reveals that the abundant fauna collected from the Aulacopleura shales at this site was confined to multiple bedding planes from a $1.4 \mathrm{~m}$ thick unit of mudstone. Individual bedding surfaces differ in the diversity and density of skeletal fossils, but the entire interval has very little evidence of infaunal burrowing. While some surfaces bearing a diverse skeletal fauna contain the trilobite Aulacopleura koninckii, on other surfaces this trilobite is overwhelmingly dominant. Dense clusters of A. koninckii on bedding surfaces contain individuals of varied mean sizes, some of which contain meraspids only. These strongly suggest that clustering behaviour was not restricted to those trilobites engaged in breeding. The sedimentary and taphonomic characteristics are consistent with morphological features of $A$. koninckii that suggest its adaptation to conditions of reduced benthic oxygen availability, and that this animal experienced marked blooms in abundance when environmental conditions were particularly favourable to it.

\section{Acknowledgements}

This study was funded by National Geographic grant $5430-95$ and National Science Foundation grant EAR-0616574. We thank Stephen K. Donovan, Mary L. Droser, Paul S. Hong, Martin J. Kennedy, David R. Pervear, Paul M. Myrow, Chris T. Reinhard and Charles E. Savrda for discussion. Carlton E. Brett and Jindřich Hladil improved the paper by providing detailed, helpful reviews. Clinton T. Scott kindly performed the geochemical analyses of carbon and sulphur in the lab of Timothy S. Lyons at UCR. For help with acquiring taphonomic data from individual slabs we particularly thank Paul S. Hong, Lidya G. Tarhan, and other stu- 
dents in the UCR paleontology graduate group. We also thank Vojtěch Turek (National Museum, Prague), Petr Budil (Czech Geological Survey), and Jessica D. Cundiff (Museum of Comparative Zoology, Harvard University) for kind access to collections in their care.

\section{References}

Allison, P.A., Wignall, P.B. \& Brett, C.E. 1995. Palaeo-oxygenation: effects and recognition, 97-112. In BosenCE, D.W.J. \& Allison, P.A. (eds) Marine Palaeoenvironmental Analysis from Fossils. Geological Society of London, Special Publication 83.

BARRANDE, J. 1846. Notice préliminaire sur le systême silurien et les trilobites de Bohême. 97 pp. Hirschfeld, Leipzig.

BARRANDE, J. 1852. Systême silurien du centre de la Bohême. Ière partie. Recherches paléontologiques. 935 pp. Privately published, Prague \& Paris.

BouČEK, B. 1941. Über einem neuen Aufschluss im Silur bei Lodenitz. Zprávy Geologického ústavu pro Čechy a Moravu 17, 165-172.

BRANDT, D.S. 2002. Ecdysial efficiency and evolutionary efficacy among marine arthropods: implications for trilobite survivorship. Alcheringa 26, 399-421.

DOI 10.1080/03115510208619264

BretT, C.E. \& Baird, G.C. 1993. Taphonomic approaches to temporal resolution in stratigraphy: examples from Paleozoic marine mudrocks, 250-274. In Kidwell, S.M. \& BeHrensMEYER, A.K. (eds) Taphonomic approaches to time resolution in the fossil record. Paleontological Society, Knoxville, Tennessee.

BRETT, C.E., BAird, G.C. \& SPEyer, S.E. 1997. Fossil Lagerstätte: Stratigraphic record of paleontological and taphonomic events, 3-40. In BRetT, C.E. \& BAIRD, G.C. (eds) Paleontological events, stratigraphic, ecological and evolutionary implications. Columbia University Press, New York.

Brett, C.E., Zambito, J.J., Hunda, B.R. \& Schindler, E. 2012. Mid-Paleozoic trilobite lagerstatten: models of diagenetically enhanced obrution deposits. Palaios 27, 326-345. DOI 10.2110/palo.2011.p11-040r

BrIght, R.C. 1959. A paleoecologic and biometric study of the Middle Cambrian trilobite Elrathia kingii (Meek). Journal of Paleontology 33, 83-98.

Chatterton, B.D.E. \& Ludvigsen, R. 1998. Upper Steptoean (Upper Cambrian) trilobites from the McKay Group of southeastern British Columbia, Canada. Journal of Paleontology, The Paleontological Society Memoir 72 (supplement to No. 2), 1-43.

ChlupÁČ, I. 1983. Trilobite assemblages in the Devonian of the Barrandian area and their relations to palaeoenvironments. Geologica et Palaeontologica 17, 45-73.

Cocks, L.R.M. \& ToRsviK, T.H. 2002. Earth geography from 500 to 400 million years ago: a faunal and palaeomagnetic review. Journal of the Geological Society 159, 631-644. DOI 10.1144/0016-764901-118

Cramer, B.D. \& Saltzman, M.R. 2007. Fluctuations in eperic sea carbonate production during Silurian positive carbon isotope excursions: a review of proposed paleooceanographic models. Palaeogeography, Palaeoclimatology, Palaeoecology 245, 37-45. DOI 10.1016/j.palaeo.2006.02.027

Crônier, C., Bartzsch, K., Weyer, D. \& Feist, R. 1999. Larval morphology and ontogeny of a late Devonian phacopid with reduced sight from Thuringia, Germany. Journal of Paleontology 73, 240-255.

Droser, M.L. \& BotTJer, D.J. 1986. A semiquantitative field classification of ichnofabric. Journal of Sedimentary Petrology $56,558-589$.

DOI 10.1306/212F89C2-2B24-11D7-8648000102C1865D

Farrell, U.C., Briggs, D.E.G. \& Gaines, R.R. 2011. Paleoecology of the olenid trilobite Triarthrus: new evidence from Beecher's trilobite bed and other sites of pyritization. Palaios 26, 730-742. DOI 10.2110/palo.2011.p11-050r

FORTEY, R.A. 2000. Olenid trilobites: The oldest known chemoautotrophic symbionts? Proceedings of the National Academy of Sciences of the United States of America 97, 6574-6578. DOI 10.1073/pnas.97.12.6574

Fortey, R.A. \& Owens, R.M. 1990. Trilobites, 121-142. In McNamara, K.J. (ed.) Evolutionary Trends. Belhaven Press, London.

Fortey, R.A. \& Owens, R.M. 1999. Feeding habits in trilobites. Palaeontology 42, 429-465.

DOI 10.1111/1475-4983.00080

Fusco, G., Hughes, N.C., Webster, M. \& Mineldi, A. 2004. Exploring developmental modes in a fossil arthropod: growth and trunk segmentation of the trilobite Aulacopleura konincki. American Naturalist 163, 167-183. DOI 10.1086/381042

Fusco, G., Hong, P.S. \& Hughes, N.C. 2014. Positional specification in the segmental growth pattern of an early arthropod. Proceedings of the Royal Society of London, Series B 281, 20133037. DOI 10.1098/rspb.2013.3037

Gaines, R.R. \& DRoser, M.L. 2003. Paleoecology of the familiar trilobite Elrathia kingii: an early exaerobic zone inhabitant. Geology 31, 941-944. DOI 10.1130/G19926.1

Gupta, V.J. \& SHAw, F.C. 1985. Lower Palaeozoic trilobites from Zanskar Valley, Ladakh, Himalaya, India. Research Bulletin (Science) of the Panjab University 36, 335-344.

Gutiérrez-Marco, J.C., SÁ, A.A., García-Bellido, D.C., RÁBANO, I. \& VALÉRIO, M. 2009. Giant trilobites and trilobite clusters from the Ordovician of Portugal. Geology 37, 443-446. DOI 10.1130/G25513A.1

Havlíček, V., VaněK, J. \& Fatka, O. 1994. Perunica microcontinent in the Ordovician (its position within the Mediterranean Province, series division, benthic and pelagic associations). Sborník geologických věd, Geologie 46, 23-56.

Henningsmoen, G. 1975. Moulting in trilobites. Fossils and Strata 4, 179-200.

Hong, P.S., Hughes, N.C. \& SHEETs, H.D.S. in press. Size, shape and systematics of Silurian trilobite Aulacopleura koninckii. Journal of Paleontology.

HornY, R. 1955. The Budnany Beds in the western part of the Silurian of the Barrandian. Sbornik Ústředního ústavu geologického, Oddíl geologický 21, 315-409.

HoRnÝ, R. 1965. Tectonic structure and development of the Silurian between Beroun and Tachlovice. $\breve{C}$ asopis pro mineralogii a geologii 10, 147-155.

Huff, W.D., Bergström, S.M. \& Kolata, D.R. 1992. Gigantic Ordovician volcanic ash fall in North America and Europe: Biological, tectonomagmatic, and event-stratigraphic significance. Geology 20, 875-878. DOI 10.1130/0091-7613(1992)020<0875:GOVAFI>2.3.CO;2

HugHES, N.C. 1999. Statistical and imaging methods applied to deformed fossils, 127-155. In HARPER, D.A.T. (ed.) Numerical Palaeobiology. John Wiley, London. 
Hughes, N.C. \& Chapman, R.E. 1995. Growth and variation in the Silurian proetide trilobite Aulacopleura konincki and its implications for trilobite palaeobiology. Lethaia 28, 333-353. DOI 10.1111/j.1502-3931.1995.tb01824.x

Hughes, N.C., Chapman, R.E. \& Adrain, J.M. 1999. The stability of thoracic segmentation in trilobites: a case study in developmental and ecological constraints. Evolution and Development 1, 24-35. DOI 10.1046/j.1525-142x.1999.99005.x

Hughes, N.C. \& Cooper, D.L. 1999. Paleobiologic and taphonomic aspects of the "granulosa" trilobite assemblage, Kope Formation (Upper Ordovician, Cincinnati region). Journal of Paleontology 73, 306-319.

Hughes, N.C., Mineldi, A. \& Fusco, G. 2006. The ontogeny of trilobite segmentation: a comparative approach. Paleobiology 32, 602-627. DOI 10.1666/06017.1

Hunda, B.R., Hughes, N.C. \& Flessa, K.W. 2006. Trilobite taphonomy and temporal resolution in the Mt. Orab Shale Bed (Upper Ordovician, Ohio, USA). Palaios 21, 26-45. DOI 10.2110/palo.2005.p05-01

KARIM, T. \& Westrop, S.R. 2002. Taphonomy and paleoecology of Ordovician trilobite clusters, Bromide Formation, south-central Oklahoma. Palaios 17, 394-402.

DOI 10.1669/0883-1351(2002)017<0394:TAPOOT>2.0.CO;2

Kohrs, R., Brett, C.E. \& O'Brien, N. 2008. Sedimentology of Upper Ordovician mudstones from the Cincinnati Arch region, Ohio/Kentucky: toward a general model of mud event deposition, 88-111. In McLaughlin, P.I., BretT, C.E. Holland, S.M. $\&$ STORRs, G. (eds) Stratigraphic renaissance in the Cincinnati Arch: Implications for Upper Ordovician paleontology and paleoecology. Cincinnati Museum Center, Cincinnati, $\mathrm{OH}$.

Ǩ̌iž, J. 1962. Nové nálezy druhu Phaetonellus dentatulus (Novák, 1890)/Neue Funde der Art Phaetonellus dentatulus (Novák, 1890) - Barrandes Lokalität Lodenice. Časopis pro mineralogii a geologii 7, 139-144.

KŘíž, J. 1991. The Silurian of the Prague Basin (Bohemia) - tectonic, eustatic and volcanic controls on facies and faunal development, 179-203. In BAssetT, M.G., LANE, P.D. \& EDWARDS, D. (eds) The Murchison Symposium: proceedings of an international conference on the Silurian System. Special Papers in Palaeontology.

KŘiž, J. 1992. Silurian Field Excursions: Prague Basin (Barrandian), Bohemia. National Museum of Wales, Geological Series 13, 1-111.

KŘíž, J. 2007. Origin, evolution and classification of the new superorder Nepiomorphia (Mollusca, Bivalvia, Lower Paleozoic). Palaeontology 50, 1341-1365. DOI 10.1111/j.1475-4983.2007.00720.x

Křiž, J., Degardin, J.-M., Ferretti, A., Hansch, W., Gutiérrez-Marco, J.C., Paris, F., Piçarra D’Almeida, J.M., Robardet, M., Schönlaub, H.-P. \& Serpagli, E. 2003. Silurian stratigraphy and paleogeography of north Gondwanan and Perunican Europe, 105-178. In LANDing, E. \& Johnson, M.E. (eds) Silurian lands and seas - paleogeography outside of Laurentia. New York State Museum Bulletin.

KŘižz, J., Dufka, P., Jaeger, H. \& Schönlaub, H.P. 1993. The Wenlock/Ludlow boundary in the Prague Basin (Bohemia). Jahrbuch der Geologischen Bundesanstalt A 136, 809-839.

LiN, J.-P. \& YUAN, J.-L. 2009. Reassessment of the mode of life of Pagetia Walcott, 1916 (Trilobita: Eosdiscidae) based on a cluster of intact exuviae from the Kaili Formation (Cambrian) of Guizhou, China. Lethaia 42, 67-73.

DOI 10.1111/j.1502-3931.2008.00104.x
LOYDELL, D.K. 2012. Graptolite biozone correlation charts. Geological Magazine 149, 124-132.

DOI 10.1017/S0016756811000513

MANDA, Š. 2008. Palaeoecology and palaeogeographic relations of the Silurian phragmoceratids (Nautiloidea, Cephalopoda) of the Prague Basin (Bohemia). Bulletin of Geosciences 83, 39-62. DOI 10.3140/bull.geosci.2008.01.039

Melchin, M.J., SAdler, P.M. \& Cramer, B.D. 2012. The Silurian Period, 525-558. In Gradstein, F.M., OGG, J.G., Schmitz, M. \& OGG, G.M. (eds) The Geologic Time Scale 2012. Elsevier, Amsterdam.

NovÁK, O.P. 1890. Vergleichende Studien an einingen Trilobiten aus den Herzyn von Bicken, Wildungen, Greifenstein und Böhmen. Paläontologische Abhandlungen, Neue Folge 1, 95-138.

Paterson, J.R., Jago, J.B., Brock, G.A. \& Gehling, J.G. 2007. Taphonomy and palaeoecology of the emuellid trilobite Balcoracania dailyi (early Cambrian, South Australia). Palaeogeography, Palaeoclimatology, Palaeoecology 249, 302-321. DOI 10.1016/j.palaeo.2007.02.004

SAdLER, P.M. 1981. Sediment accumulation rates and the completeness of stratigraphic sections. Journal of Geology 89, 565-584. DOI 10.1086/628623

SAvRdA, C.E. \& BotTJER, D.J. 1987. The exaerobic zone, a new oxygen-deficient marine biofacies. Nature $327,54-56$. DOI $10.1038 / 327054 a 0$

SeKIGUCHI, K. 1988. Biology of Horseshoe Crabs. 428 pp. Tokyo, Science House.

SPEYER, S.E. 1987. Comparative taphonomy and paleoecology of trilobite lagerstätten. Alcheringa 11, 205-232. DOI 10.1080/03115518708618989

SPEYER, S.E. \& BRETT, C.E. 1985. Clustered trilobite assemblages in the Middle Devonian Hamilton Group. Lethaia 18, 85-103. DOI 10.1111/j.1502-3931.1985.tb00688.x

SuZuki, Y. \& Bergström, J. 2008. Respiration in trilobites. Geologiska Föreningens $i$ Stockholm Förhandlingar 130, 211-229.

Talent, J.A, Brock, G.A., Engelbretsen, M.A., Gaetani, M., Jell, P.A., Mawson, R., Talent, R.C. \& Webster, G.D. 1990. Himalayan palaeontologic database polluted: Plagiarism and other anomalies. Journal of the Geological Society of India 35, $569-585$.

Thomas, A.T. \& Lane, P.D. 1984. Autecology of Silurian trilobites. Special Papers in Palaeontology 32, 55-69.

VANĚK, J. 1966. Studie o trilobitové fauně ,aulakopleurových břidlic" na lokalitě Černidla u Loděnice. Zprávy o geologických výzkumech v roce 1965, 113-114.

VANĚK, J. 1990. Exact age of several localities in the Liteň Formation, Motol Member (Wenlock, Central Bohemia). Věstník Ústředního ústavu geologického 65, 119-124.

Verniers, J., Maletz, J., Křižz, J., Žigaité, Ž., Paris, F., SchÖNlaub, H.-P. \& Wrona, R. 2008. Silurian, 249-302. In McCann, T. (ed.) The Geology of Central Europe, Volume 1: Precambrian and Palaeozoic. The Geological Society, London.

Webster, M., Gaines, R.R. \& Hughes, N.C. 2008. Microstratigraphy, trilobite biostratinomy, and depositional environment of the "lower Cambrian" Ruin Wash lagerstätte, Pioche Formation, Nevada. Palaeogeography, Palaeoclimatology, Palaeoecology 284, 100-122. DOI 10.1016/j.palaeo.2008.04.002

Whittington, H.B. 1986. Late middle Cambrian trilobites from Zanskar, Ladakh, northern India. Rivista Italiana di Paleontologia e Stratigrafia 92, 171-188. 